\title{
11. UPPER OLIGOCENE TO RECENT PLANKTONIC FORAMINIFERAL REMAINS IN SEDIMENTS OF THE INNER WALL OF THE MIDDLE AMERICA TRENCH WITH SPECIAL EMPHASIS ON GLOBOROTALIA ${ }^{1}$
}

\author{
Georgette Glaçon and Jacques Bourgois, Département de Géotectonique, Université Pierre et Marie Curie ${ }^{2}$
}

\begin{abstract}
This study presents a rough biostratigraphy based on the planktonic foraminifers. After a comparison with the biostratigraphy of M. Filewicz, based on nannofossils, we list the relicts of the Globorotalia lineages preserved.
\end{abstract}

\section{INTRODUCTION}

Species of Neogloboquadrina and Globorotalia are among the most dissolution-resistant planktonic foraminifers found in sediments of the inner wall of the Middle America Trench. Despite the dissolution and slope resedimentation that occur in this seismically active area, we recognized parts of the phyletic history of these foraminifers that are useful for biostratigraphic and sedimentary interpretation. We identified a number of morphological changes in the Globorotalia group and tried to use them for local Pliocene-Pleistocene stratigraphic correlations. We believe that some of these morphological changes could be useful in paleoenvironmental studies but feel that a better knowledge of morphological trends in living globorotaliids is necessary for a better understanding.

During Leg 84 of the Glomar Challenger, six sites were chosen in the Guatemala and Costa Rica active margins (Fig. 1, Table 1). In addition to contributing to our knowledge of the geological structure of the margin (Aubouin, von Huene, et al., 1982), the bathymetric distribution of five holes along an east-west transect off Guatemala, in water depths ranging from 1718 to $5529 \mathrm{~m}$, offers an opportunity to study the modalities of the dissolution of planktonic foraminiferal tests at increasing water depths and the modalities of the sedimentation on the slope at that convergent extensive margin. The sites are localized Area 9 of Coulbourn, Parker, and Berger (1980), where "changes in relative abundance (of planktonic foraminiferal tests) are too subtle to define the lysocline."

\section{MATERIALS AND METHODS}

Approximately 700 samples were analyzed for their planktonic foraminiferal content. Of these, $35810-\mathrm{cm}^{3}$ samples were collected on board, and $36620-\mathrm{cm}^{3}$ samples were subsequently collected by the senior author at the DSDP core repository.

The $20-\mathrm{cm}^{3}$ samples were dried at $60^{\circ} \mathrm{C}$ for about $18 \mathrm{hr}$. and then weighed before being washed through series of sieves with mesh sizes of $500,200,125$, and $50 \mu \mathrm{m}$, respectively. Each size fraction was again

\footnotetext{
${ }^{1}$ von Huene, R., Aubouin, J., et al., Init. Repts. DSDP, 84: Washington (U.S. Govt. Printing Office).

2 Address: Département de Géotectonique, Université Pierre et Marie Curie, 4, Place Jussieu, 75230 Paris Cedex 05, France.
}

dried at $60^{\circ} \mathrm{C}$ and weighed; $10-\mathrm{cm}^{3}$ samples were separated into the same size fractions but were not weighed.

Quantitative analysis of the planktonic foraminifer assemblages was performed on the $20-\mathrm{cm}^{3}$ samples for the fraction larger than $200 \mu \mathrm{m}$ and, in some cases, for the fraction larger than $125 \mu \mathrm{m}$. Counts included about 1000 individuals. If the samples contained more than this number of individuals, a split of the sample was counted. Extremely few planktonic foraminifers were found on the $50-\mu \mathrm{m}$ sieve, possibly as a result of dissolution or winnowing. The experience of Berger and Piper (1972) shows how difficult it can be to differentiate between dissolution and transport "since sediments containing only heavy resistant foraminifera may result from dissolution of less resistant tests or from bottom currents winnowing out the lighter tests."

In the $10-\mathrm{cm}^{3}$ samples we made a semiquantitative estimate of the abundance of the species. The sample was poured onto a tray divided in squares. Depending on the size of the studied fraction, the side of the square is $2.5 \mathrm{~cm}$ for the fraction larger than $500 \mu \mathrm{m}, 1 \mathrm{~cm}$ for the fraction between 500 and $200 \mu \mathrm{m}, 0.6 \mathrm{~cm}$ for the fraction between 200 and $125 \mu \mathrm{m}$, and $0.25 \mathrm{~cm}$ for the fraction between 125 and $50 \mu \mathrm{m}$. At least 10 squares were examined. The relative abundance of species or morphotypes is: $\mathrm{r}$ (rare)-when only 1 specimen is present in a minimum area of three squares or more; $\mathrm{c}$ (common)-when a specimen is present in an area of about two squares; $f$ (frequent)-when no more than 9 individuals occur in every square; a (abundant) - when 10 to 30 individuals occur in a square; and va (very abundant) - when more than 30 individuals occur in every square.

\section{Biostratigraphy}

In order to place our study into a regional biostratigraphic framework we compiled biostratigraphic studies in the East Pacific calibrated by various authors on the paleomagnetic time scale for the early Miocene to Recent (Figs. 2 and 3). For our geological time scale we chose the dates of the paleomagnetic anomalies calculated by Lowrie and Alvarez (1981). For the middle and early Miocene the calibration on the paleomagnetic time scale is indirect, and some discrepancies still exist, chiefly for the Langhian and Serravallian stages.

Among the biostratigraphic studies of various microfossil groups conducted-on Leg 84 material, only that of the calcareous nannofossils (Filewicz, this volume) was available to us at the time of this study; we use Filewicz's nannozonation extensively to calibrate coiling changes in Pulleniatina and Globorotalia found in our samples. Because we need to place the Globorotalia study in a planktonic foraminiferal framework, we examined all the planktonic foraminiferal assemblages. Results of our observations are given as range charts (Tables 2-12) and summarized (Figs. 4-8). Site by site discussion occurs after the following brief examination of dissolution effects.

\section{Dissolution Analysis}

Results of counts are summarized in Tables 2 to 12 . Evidence of dissolution of the planktonic foraminiferal tests, as illustrated by Bé, Morse, and Harrison (1975), is present throughout the cores. Degree of dissolution ranges from shells that are partly abraded, to fragmented, to totally eliminated. Site 570 off Guatemala, is the shallowest site, with a water depth of about $1700 \mathrm{~m}$; Cores 570-1 to -21 exhibit 


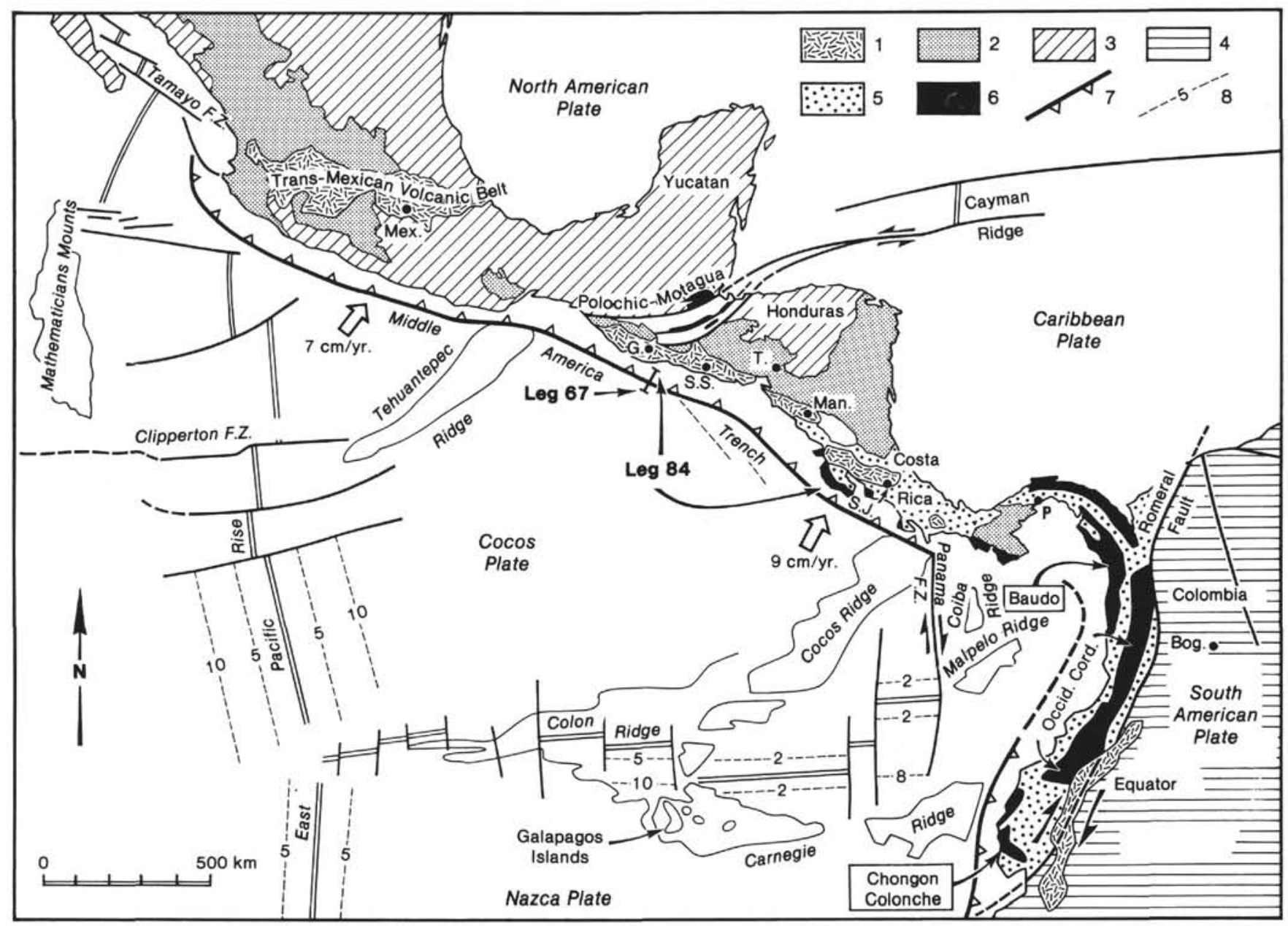

Figure 1. Location of Legs 84 and 67; present-day plate motion from Minster and Jordan (1978). 1 = Pliocene and Pleistocene volcanism, $2=$ Oligocene and Miocene volcanism, $3=$ North American Plate, $4=$ South American Plate, $5=$ Cenozoic formations, Andes and southern Central America, 6 = Mesozoic and Cenozoic ophiolitic complexes, $7=$ subduction zones, $8=$ magnetic anomalies.

Table 1. Locations of the sites.

\begin{tabular}{ccccr}
\hline Off & $\begin{array}{c}\text { Site } \\
\text { or } \\
\text { hole }\end{array}$ & Latitude (N) & Longitude (W) & $\begin{array}{r}\text { Water } \\
\text { depth } \\
(\mathrm{m})\end{array}$ \\
\hline \multirow{5}{*}{ Guatemala } & 570 & $13^{\circ} 17.12^{\prime}$ & $90^{\circ} 23.57^{\prime}$ & 1718 \\
& 568 & $13^{\circ} 04.33^{\prime}$ & $90^{\circ} 48.00^{\prime}$ & 2031 \\
& 569 & $12^{\circ} 56.31^{\prime}$ & $90^{\circ} 50.35^{\prime}$ & 27997 \\
Costa Rica & $567 \mathrm{~A}$ & $12^{\circ} 42.99^{\prime}$ & $90^{\circ} 55.92^{\prime}$ & 5529 \\
& 565 & $9^{\circ} 43.69^{\prime}$ & $86^{\circ} 05.44^{\prime}$ & 3111 \\
\hline
\end{tabular}

incomplete dissolution of planktonic foraminiferal shells with significant fluctuations in the number of preserved species or phenotypesfrom 14 to only 1 . The last species to remain in the Quaternary is usually Neogloboquadrina eggeri (Rhumbler) and in the Pliocene $N$. humerosa (Takayanagi and Saito). At Site 565 off Costa Rica in $3111 \mathrm{~m}$ water depth, by contrast, the most resistant forms in the Pliocene and Quaternary are species of Globorotalia.

In the middle and lower Miocene, Globoquadrina appears to be the most dissolution-resistant form, followed next by Globorotalia, and then by Globigerinoides. These results are summarized in Figures 4 to 8 with a column proportional in width to the number of genera present in the samples. In that scheme possible reworking of fauna is not taken into account, although reworking is probably responsible for the better preservation at some levels, as is discussed later. Seven dissolution ranks have been distinguished:

Rank 1: No planktonic foraminiferal shell remains in the sample.

Rank 2: Species of only one genus remain.

Rank 3: Species of only two genera remain, usually Neogloboquadrina or Globoquadrina and Globorotalia.

Rank 4: Species of three genera occur-two of those mentioned under Rank 3 together with Pulleniatina or, surprisingly, often Globigerinoides (not small-sized specimens), as might be expected in fecal pellets, but specimens larger than $200 \mu \mathrm{m}$ ).

Rank 5: More than three genera occur, but for a $20-\mathrm{cm}^{3}$ sample the total number of planktonic individuals is less than 500 in the fraction coarser than $200 \mu \mathrm{m}$;

Rank 6: More than three genera occur, and the number of specimens is between 500 and 1000 in the fraction coarser than $200 \mu \mathrm{m}$ for a 20 - $\mathrm{cm}^{3}$ sample;

Rank 7: More than three genera and more than 1000 planktonic foraminifers occur in the fraction coarser than $200 \mu \mathrm{m}$ for a $20-\mathrm{cm}^{3}$ sample.

Rank 1 is below the planktonic foraminiferal CCD (calcite compensation depth). We assume that ranks 6 and 7 could be on either side of the planktonic foraminiferal lysocline (Berger, 1970). Other dissolution indexes given in Tables 2 to 12 include (1) levels where fragmentation of planktonic foraminifers is significant; (2) the size of the largest fragments, and (3) the number of benthic foraminifers coarser than $200 \mu \mathrm{m}$ found in a $20-\mathrm{cm}^{3}$ sample. 


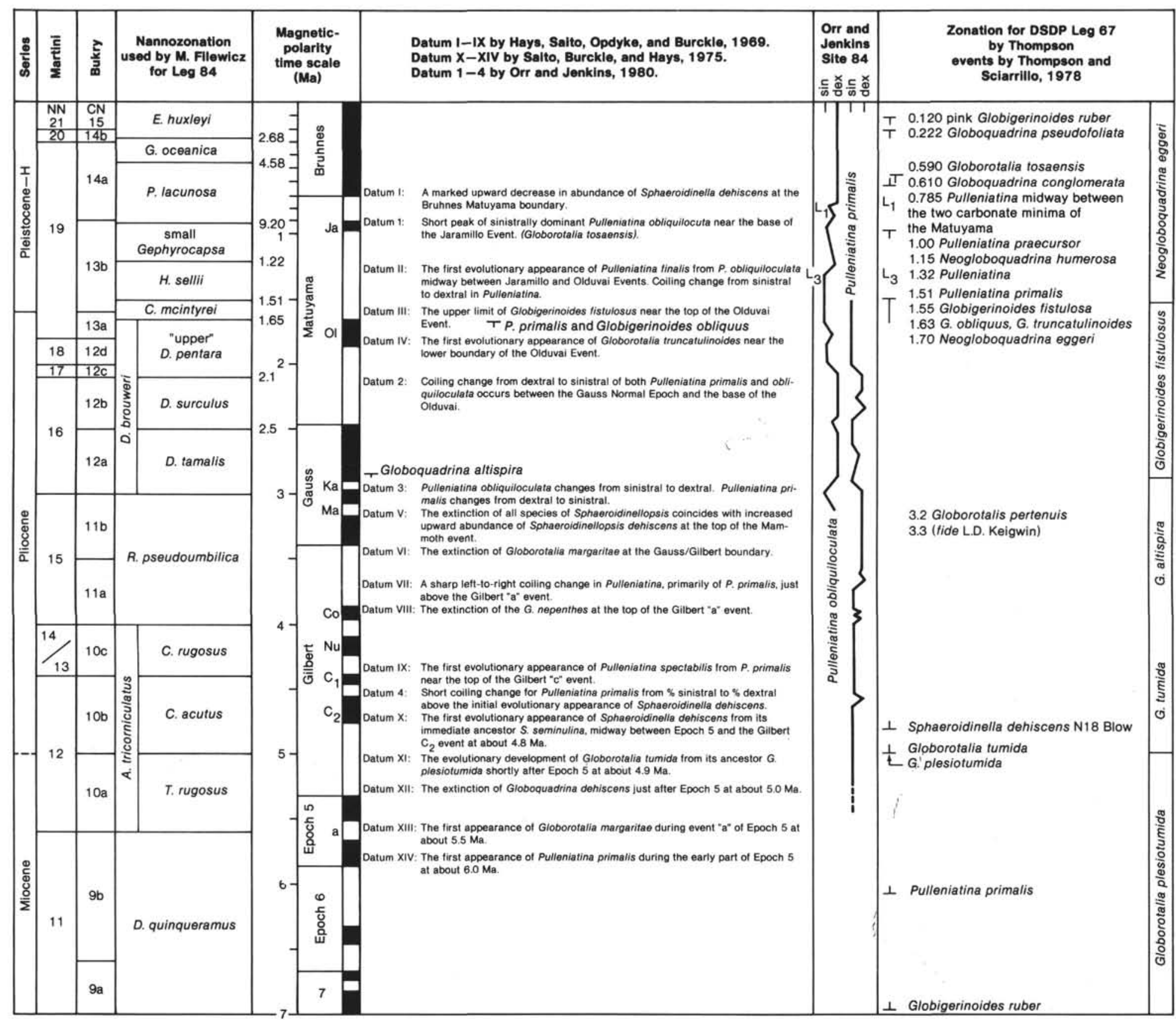




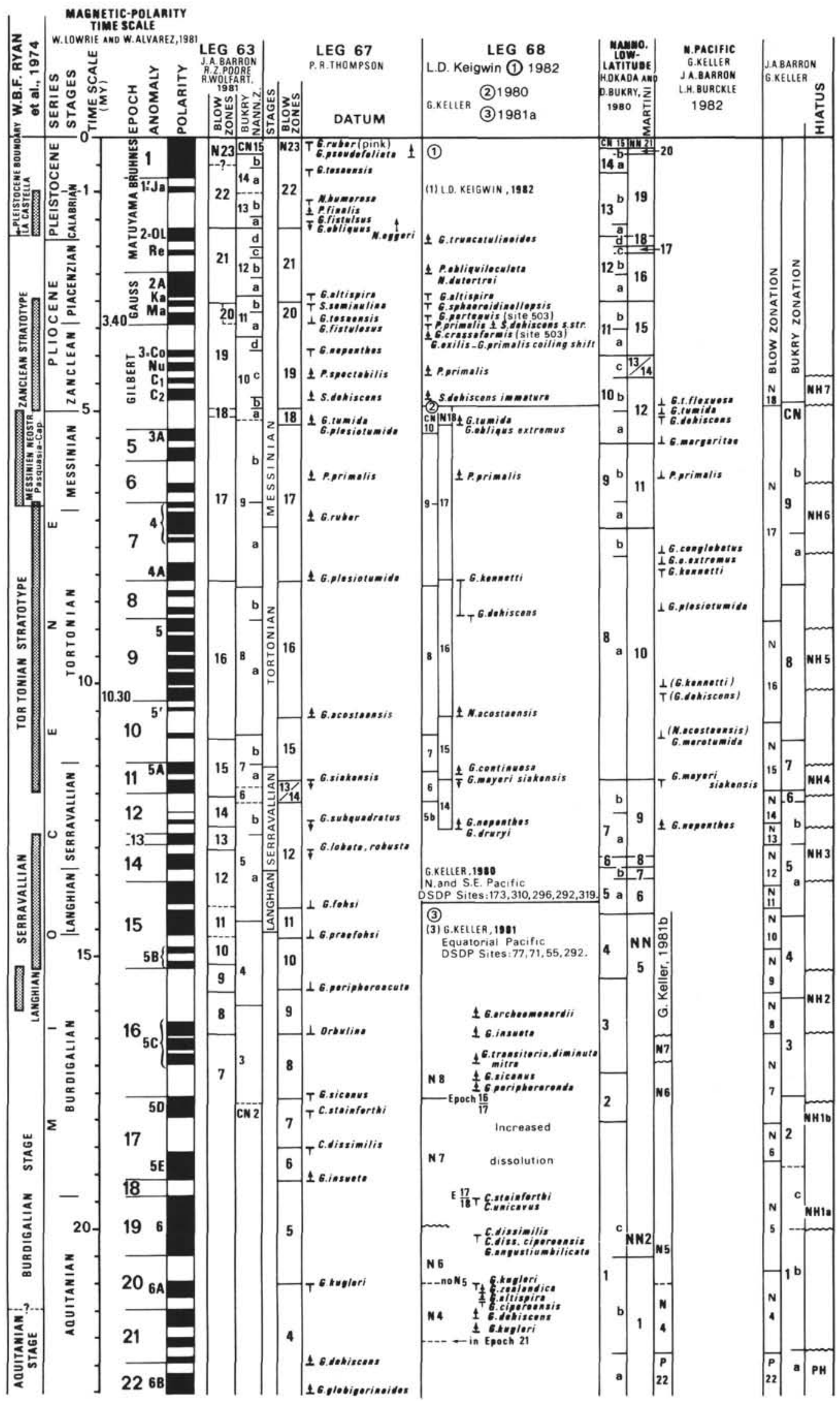

Figure 3. Comparison of post-early Miocene and younger biozonations used for East Equatorial Pacific foraminiferal ooze. Parentheses around species names in the N. Pacific column indicate boreal datum level. In the Leg 68 column, the circled numbers refer to the following citations: (1) L. D. Keigwin, 1982; (2) G. Keller, 1980; and (3) G. Keller, 1981a. 


\section{BIOSTRATIGRAPHY AT EACH SITE}

\section{Site $\mathbf{5 7 0}$}

Site 570 is located on the edge of a small bench in the upper slope of the Middle America Trench at a water depth of $1718 \mathrm{~m}$ (Fig. 4, Tables 2-4).

Dissolution of planktonic foraminifers is not complete in the first 21 cores retrieved and in the two first sections of Core 570-22, but strong fluctuations exist; species of only one genus remain in Sample 570-19-1, 64-66 cm and only two genera in Samples 570-1-3, $39-41 \mathrm{~cm}$; and 570-2-1, 123-125 cm, and 570-10-1, 37$39 \mathrm{~cm}$.

Pink Globigerinoides ruber appears from Sample 570$8-2,14-18 \mathrm{~cm}$ to $570-2-2,20-25 \mathrm{~cm}$ but is well represented by many specimens only from Samples 570-5-4, $70-77 \mathrm{~cm}$ to $570-3-2,15-20 \mathrm{~cm}$. Bé and Hamlin (1967) identified pheophytin as the pink pigment in G. ruber, and Orr (1967) wrote that the pigmenting element has an ephemeral nature, therefore "rapid sedimentation rate should preserve more pigmented specimens in a given geographic area." Perhaps stronger dissolution could explain the lack of pink ruber from deeper cores. In the samples we studied, the occurrence of $G$. ruber indicates an age older than $0.120 \mathrm{Ma}$.

Globigerina calida occurs in low numbers from Sample 570-3-1, 73-78 cm to the top of Core 570-1. Following Bolli and Premoli Silva (1973), the phyletic appearance of that species is dated $0.140 \mathrm{Ma}$. At Site 570 , the first appearance of that species is delayed because of dissolution.

The presence of Globoquadrina conglomerata in Sample $570-3-6,88-90 \mathrm{~cm}$ indicates an age younger than $0.610 \mathrm{Ma}$ for this level (Thompson and Sciarrillo, 1978).

Filewicz (this volume) places the upper boundary of the small Gephyrocapsa Zone in Core 570-6, therefore the peak of left-coiled Pulleniatina obliquiloculata found in Sample 570-6-4, 43-46 cm appears to correspond to the second peak on the coiling curve of Orr and Jenkins (1980) "near the basis of the Jaramillo event" dated 0.97 Ma by Lowrie and Alvarez (1981). If this assumption is correct, the peak $\mathrm{L}_{1}$ of the same curve dated $0.785 \mathrm{Ma}$ is close to Sample 570-5-2, 85-90 cm, in which rare sinistral specimens of $P$. obliquiloculata appear. Dextral Pulleniatina finalis occur sporadically in Core 570-3; they were probably transported into the area.

Because of a gap in core recovery no interpretation is given for the next peak of the coiling curve.

The coiling change in both $P$. primalis and $P$. obliquiloculata in Sample 570-23-4, 66-70 cm is correlated to Datum 2 of Orr and Jenkins (1980) between the Gauss Normal Epoch and the Olduvai (1.87-2.47 Ma), an interpretation in agreement with Filewicz (that volume), who places the lower boundary of the Calcidiscus mcintyrei Zone (1.65 Ma) between Sections 570-23-4 and 570-23-6. The co-occurrence of Sphaeroidinellopsis paenedehiscens and Sphaeroidinella dehiscens in Sample $570-23-4,66-70 \mathrm{~cm}$ is probably a result of reworking caused by slope sedimentation.

We suggest that the third coiling change $\mathrm{L}_{3}$ "midway between Jaramillo and Olduvai" (part of the Datum II of Hays et al. [1969]) occurs in Sample 570-15-2, 55-56 $\mathrm{cm}$. That is in agreement with the basis of the small $\mathrm{Ge}$ phyrocapsa Zone (1.22 Ma) in Sample 570-8,CC (Filewicz, this volume).

We also suggest that Datum VII of Hays et al. (1969), "just above the Gilbert ' $a$ ' event," corresponds to the coiling change from left to right in Pulleniatina primalis in Sections 570-26-1 to 570-25-3, in agreement with Filewicz (this volume), who places Section 570-25, CC in the Reticulofenestra pseudoumbilica Zone.

Globigerinoides obliquus and G. extremus have an unique appearance in Sample 570-26-4, 14-16 cm just above a long sequence barren of planktonic foraminifers with only two exceptions: in Sample 570-34-1, 126$128 \mathrm{~cm}$ some Neogloboquadrina acostaensis and N. humerosa occur, and in Sample 570-32-1, 11-13 cm the first relicts of keeled Globorotalia of Group 3 of Tjalsma (1971) appear. Because of their tumid profile these forms are assigned to $G$. merotumida Banner and Blow. In contrast to the right-coiled holotype, the specimens here are sinistral. That species indicates a zonal interval from N16 to N18 Blow, in agreement with nannofossil data (Discoaster quinqueramus Zone).

\section{Site 568}

Site 568 is located on the upper slope of the Middle America Trench in $2031 \mathrm{~m}$ of water (Fig. 5, Tables 5-11). Compared to the previous site, there is an increase in dissolution. Almost all samples appear to have been deposited between the planktonic foraminiferal lysocline and CCD. Only four levels have more than 1000 individuals larger than $200 \mu \mathrm{m}$ in $20 \mathrm{~cm}^{3}$ of sediment.

Globigerina calida appears sporadically in low numbers in Samples 568-3-4, 38-42 cm and 568-2-3, 102-104 $\mathrm{cm}$, dating those as younger than $0.140 \mathrm{Ma}$.

Pink Globigerinoides ruber occurs from Sample 568$10-4,118-122 \mathrm{~cm}$ to Sample 568-6-2, 22-26 cm. The disappearance of this species seems to be related to dissolution.

$\mathrm{L}_{1}$, the last coiling change in Pulleniatina obliquiloculata in the Pseudoemiliania lacunosa Zone, occurs in Sample 568-10-1, 53-55 cm, dated 0.785 Ma. Poor recovery doesn't permit a detailed study of coiling changes in Pulleniatina; peak $\mathrm{L}_{2}$, however, could be above Sample 568-12-1, 65-67, which is in the small Gephyrocapsa Zone. The third peak from the top in Sample 568-20-3, $75-77 \mathrm{~cm}$ is correlated to $\mathrm{L}_{3}$, between 0.97 and $1.66 \mathrm{Ma}$ in age.

Sinistral Pulleniatina primalis occurs in Sample 56821-1, 113-116 cm just above levels barren of planktonic foraminifers; the base of the Pleistocene should be close to that level.

Globoquadrina altispira occurs just below the zone barren of planktonic foraminifers, but Pulleniatina is missing, as in the lower levels. Based on nannofossil data, the Miocene-Pliocene boundary occurs in the interval between Core 568-22 and Sample 568-25-2, 14-18 cm.

From Cores $568-25$ to -44 , remains of various Miocene phyletic stocks occur.

Globigerinoides lineages. In the lowest sample with planktonic shells preserved, $(568-44-4,62-66 \mathrm{~cm})$, G. pri- 


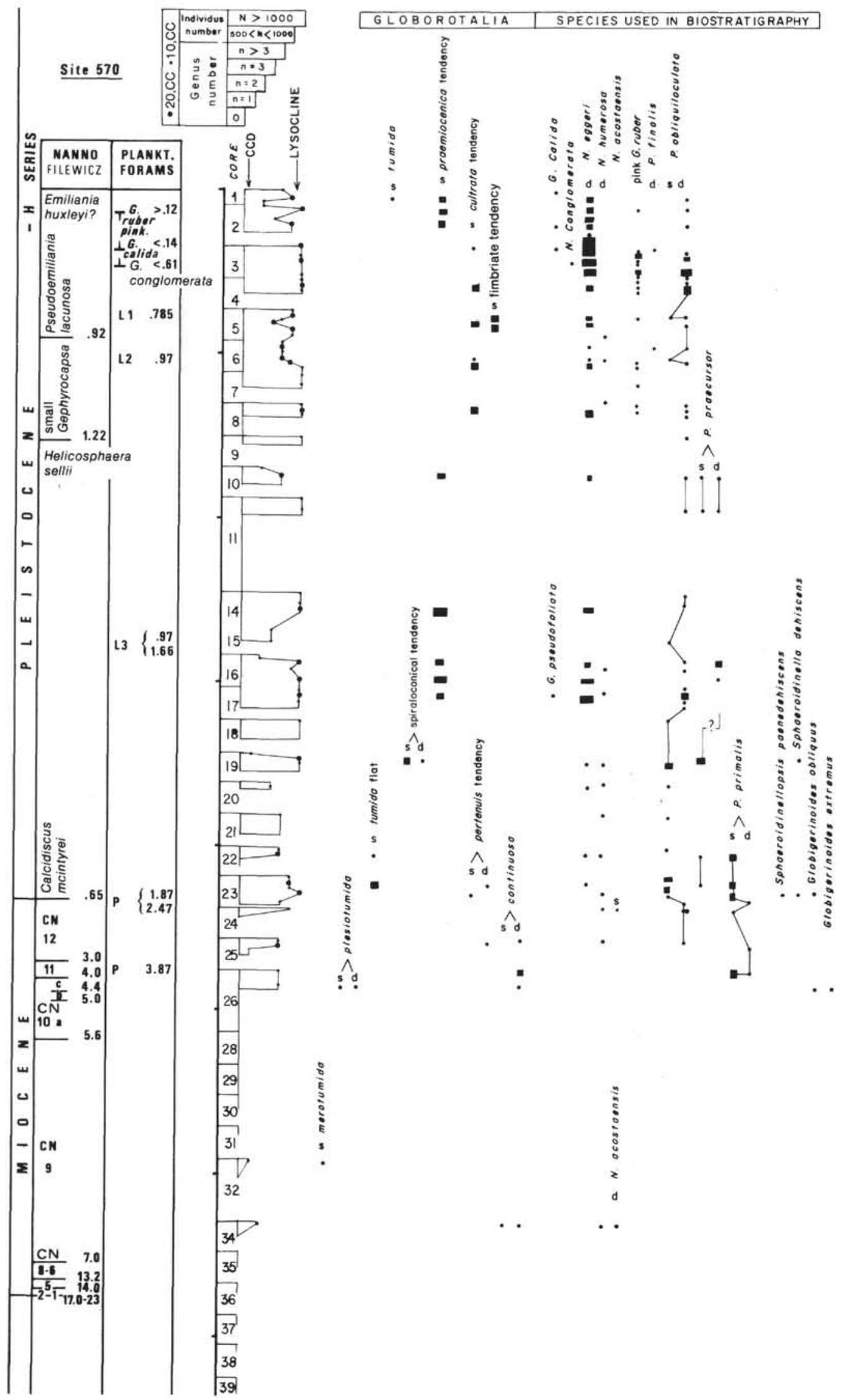

Figure 4. Biostratigraphic summary of Site 570. Solution ranking at the top of the sedimentary column has seven dissolution ranks, as discussed in the text Dissolution Analysis portion of the Materials and Methods section; $\mathrm{s}=$ sinistral, $\mathrm{d}=$ dextral. 
mordius occurs together with its probable ancestor Globigerina praebulloides. G. altiaperturus first appears in Sample 568-41-4, 80-84 cm within nannofossil Zone CN3.

Globigerinoides trilobus appears in Sample 568-42-4, $91-95 \mathrm{~cm}$, as G. trilobus immaturus, within the interval CN2-CN3. It is noteworthy that G. trilobus, with its smaller apertures, is more resistant to dissolution than G. altiaperturus, given that the presence of both species is a result of a decrease in dissolution.

A third Globigerinoides lineage is indicated only by G. subquadratus, which appears sporadically from Samples $568-41-1,80-84 \mathrm{~cm}$ to $568-32-5,52-56 \mathrm{~cm}$.

Orbulina lineage. No Praeorbulina was found. Orbulina suturalis appears in Sample 568-37-2, 118-122 cm within the "right" Sphenolithus heteromorphus Nannozone but just above levels barren of planktonic foraminifers. Therefore this first appearance may also result from a decrease in dissolution. Orbulina universa is well represented from Sample 568-33-5, 23-27 cm.

Fohsella lineage. In Sample 568-44-4, 52-56 cm, at a level selected between mottles not greatly affected by dissolution, we found specimens of the Fohsella kugleri group together with Globigerina praebulloides and some Globigerinoides primordius. Above this level dissolution prevents the identification of evolutionary steps in the $F$. kugleri group, as given in Keller (1981b). No Globoquadrina were found. Sections 568-44-4 to 568-42-7 are assigned to Nannozones CN1-CN2 (Filewicz, this volume). Above a dissolution interval, $F$. peripheroronda first appears in Core 568-41. Populations of this species show a coiling change from dextral to sinistral in Core $568-40$, then are dominantly sinistral with some dextral individuals in Core 568-37 and disappear above Core 568-28. Randomly coiled $F$. peripheroacuta appear in Core 568-29 and range up to Core 568-27, where dominantly sinistral $F$. praefohsi occur. The appearance of $F$. peripheroronda in a core not too strongly affected by dissolution is probably a real "First Appearance Datum" (FAD) (within Zone $\mathrm{CN} 3$ ) as well as those of $F$. peripheroacuta $(=$ Zone $\mathrm{N} 10 \mathrm{Blow})$ and $\mathrm{F}$. praefohsi $(=$ Zone N11 Blow), within Zones CN4 and CN5a, respectively.

Globorotalia and Neogloboquadrina ancestors. Paragloborotalia or Jenkinsella are well represented by a plexus of forms in the lower samples, in which it is possible to identify randomly coiled specimens intermediate between $P$. nana and Neogloboquadrina continuosa and some $P$. mayeri (Cushman and Ellisor) emend. Bolli and Saunders (1982).

Globorotalia menardii lineage. The following species represent parts of the lineage: sinistral " $A$ "-type chambered G. praescitula (Bizon and Glaçon, 1978), in agreement with previous observations of Tjsalma (1971) and Zachariasse (1975), appears first without record of its ancestor as an invader of the middle latitudes, as was suggested in the phyletic scheme of Srinivasan and Kennett (1981). G. praescitula ("B"-type chambered) follows and becomes randomly coiled before its disappearance; the last individuals are dextral. Sinistral $G$. praemenardii appears slightly before sinistral $G$. archeomenardii, then becomes randomly coiled. The last $G$. praemenardii are dextral. No "C"-type chambered, wholly keeled $G$. menardii were found.

Globorotalia tumida ancestors. No true $G$. lenguaensis was found. Among the "B"-type chambered G. praemenardii populations, some individuals with an oval equatorial outline and a relatively large last chamber resemble $G$. paralenguaensis (Sample 568-25-6, 65-67 cm). A similar observation was made by Bizon and Glaçon (1978) in the Mediterranean area, where some advanced "B"-type chambered G. praescitula with rounded equatorial outline closely resembling $G$. lenguaensis occur together with primitive $G$. praemenardii. We were hoping to obtain better documentation of this lineage in the present material from the Pacific Ocean for comparison with the Mediterranean fauna. The poor preservation of our material, however, makes such a comparison very difficult.

A summary of our interpretation of the nature of first and last appearances of Globorotaliids and $\mathrm{NeO}$ globoquadrina at Site 568, based mainly on calibration to the nannozonation of Filewicz (this volume), is listed as follows:

\begin{tabular}{|c|c|c|}
\hline Species & $\begin{array}{l}\text { FA and LA } \\
\text { in sample } \\
\text { (interval in } \mathrm{cm} \text { ) }\end{array}$ & $\begin{array}{l}\text { Nature of } \\
\text { event }\end{array}$ \\
\hline $\begin{array}{l}\text { Forms intermediate } \\
\text { between Para- } \\
\text { globorotalia } \\
\text { nana and Neo- } \\
\text { globoquadrina } \\
\text { continuosa }\end{array}$ & $\begin{array}{l}\text { LA: } 568-44-3,137-139 \\
\text { FA: } 568-44-4,62-66\end{array}$ & $\begin{array}{l}\text { Dissolution event } \\
\text { Dissolution event }\end{array}$ \\
\hline $\begin{array}{l}\text { Neogloboquadrina } \\
\text { continuosa }\end{array}$ & $\begin{array}{l}\text { LA: } 568-35-2,86-88 \\
\text { FA: } 568-40-5,70-74\end{array}$ & $\begin{array}{l}\text { Local event } \\
\text { Dissolution event }\end{array}$ \\
\hline $\begin{array}{c}\text { Paragloborotalia } \\
\text { acrostoma }\end{array}$ & FA: $568-30-4,86-90$ & $\begin{array}{l}\text { LA in S. Pacific, } \\
\text { a little above } \\
\text { the FA of } \\
\text { O. suturalis } \\
\text { (Srinivasan } \\
\text { and Kennett, } \\
\text { 1981) } \\
\text { Invader from } \\
\text { high latitudes }\end{array}$ \\
\hline $\begin{array}{l}\text { Paragloborotalia } \\
\text { mayeri }\end{array}$ & $\begin{array}{l}\text { LA: } 568-29-3,90-92 \\
\text { FA: } 568-44-4,62-66\end{array}$ & $\begin{array}{l}\text { Local event } \\
\text { Dissolution event }\end{array}$ \\
\hline $\begin{array}{l}\text { Globorotalia } \\
\text { praescitula }\end{array}$ & $\begin{array}{l}\text { LA: } 568-33-4,76-77 \\
\text { FA: } 568-39-4,63-65\end{array}$ & $\begin{array}{l}\text { ? No firm con- } \\
\text { trol by nan- } \\
\text { nofossils } \\
\text { Local event }\end{array}$ \\
\hline $\begin{array}{l}\text { Globorotalia } \\
\quad \text { archeomenardii }\end{array}$ & $\begin{array}{l}\text { LA: } 568-30-4,86-90 \\
\text { FA: } 568-35-4,8-12\end{array}$ & $\begin{array}{l}\text { ? No firm } \\
\text { control } \\
\text { Local event }\end{array}$ \\
\hline $\begin{array}{l}\text { Globorotalia } \\
\quad \text { praemenardii }\end{array}$ & $\begin{array}{l}\text { LA: } 568-25-6,65-67 \\
\text { FA: } 568-36-5,31-35\end{array}$ & $\begin{array}{l}\text { Dissolution event } \\
\text { FA, but no firm } \\
\text { control by } \\
\text { nannofossils }\end{array}$ \\
\hline
\end{tabular}

Note: FA and LA = first and last appearance.

Other stratigraphically important species present in the section include: (1) Globigerina ciperoensis, which makes a short appearance in Samples 568-41-2, 136-140 


\section{G. GLAÇON, J. BOURGOIS}

Table 2. Distribution of foraminifers at Site 570 .

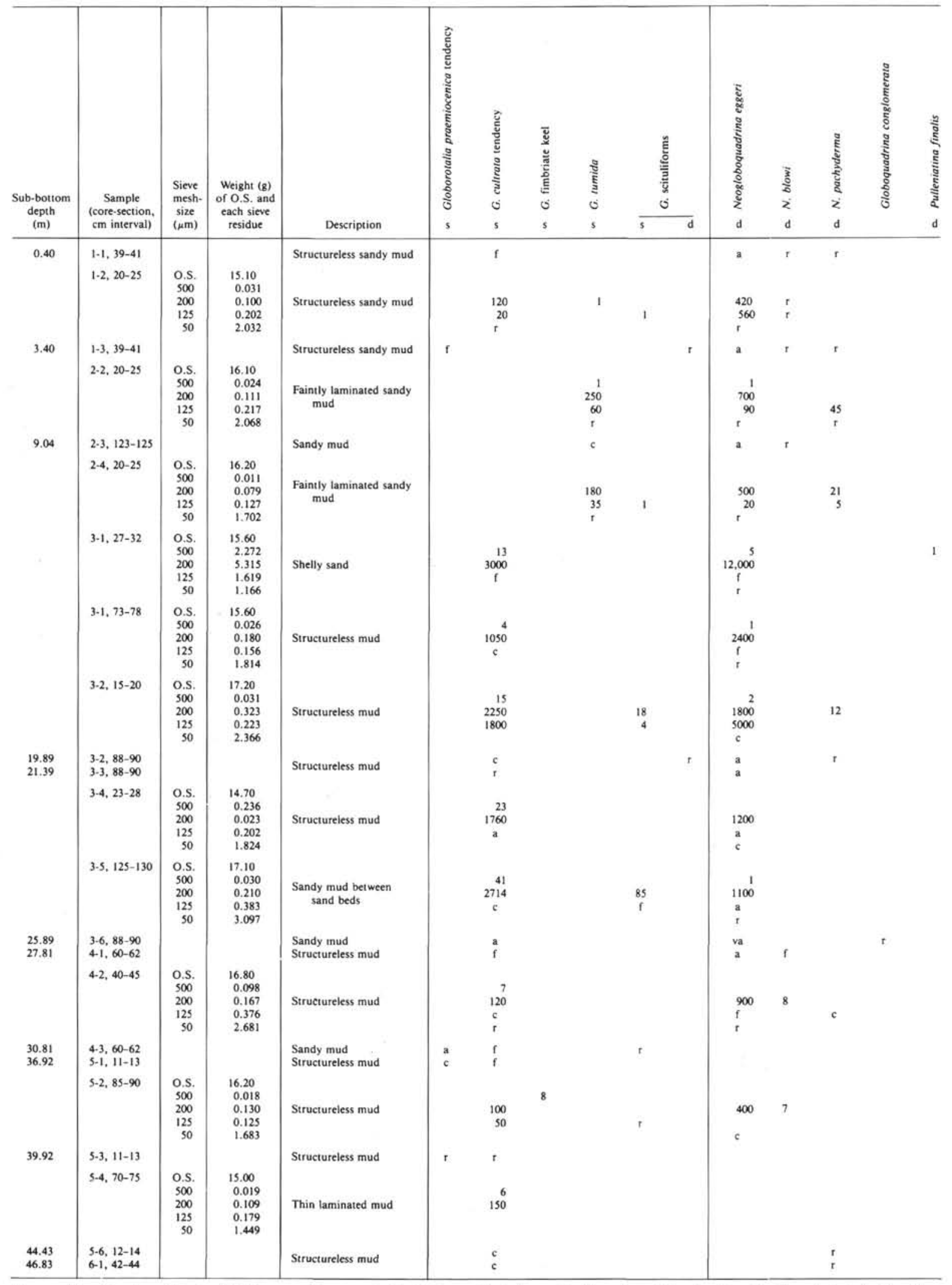

Note: $\mathrm{s}=$ sinistral, $\mathrm{d}=$ dextral; "tendency" indicates resemblance to species listed; $O . S$. = original sediment; $10-\mathrm{cm}^{3}$ samples are differentiated from $20-\mathrm{cm}{ }^{3}$ samples by having the sub-bottom depth given at left. Numbers indicate number of specimens counted. When no count was performed, abundance is given as: $r$ (rare), $c$ (common), $f$ (frequent), a (abundant), va (very abundant), vr (very rare), and vvr (more rare than vr), following a semiquantitative scale explained in the Materials and Methods section of the chapter. In the last column (Fragments of planktonic foraminifers), abundance is given with these same symbols and sizes (in $\mu \mathrm{m}$ ) as indicated; $\mathrm{K}=$ keel. In Samples 570-5-6, 12-14 cm and 570-6-1, 42-44 cm, reworked Camerini-
dae were found. 
Table 2. (Continued).

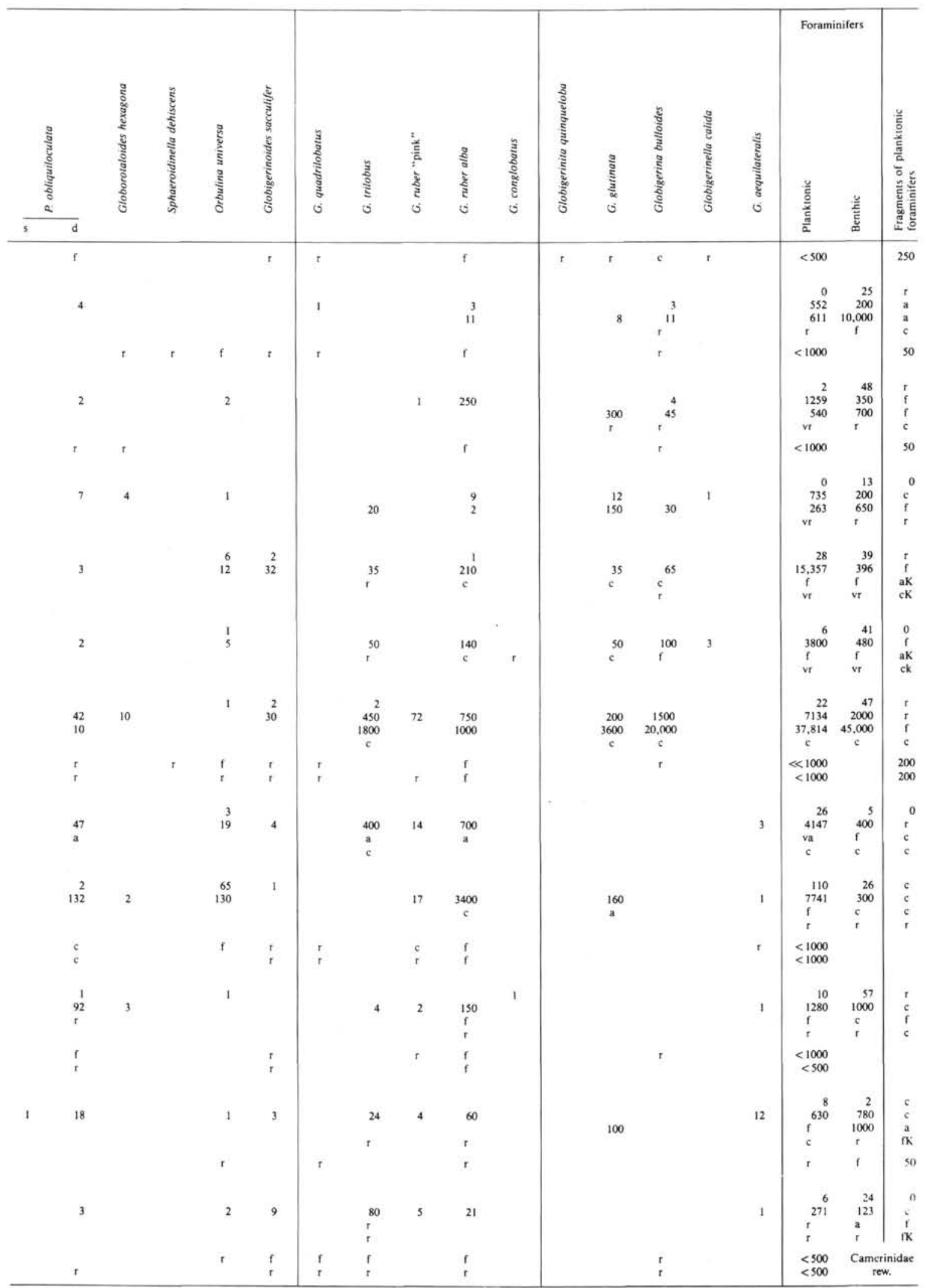




\section{G. GLAÇON, J. BOURGOIS}

Table 3. Distribution of foraminifers at Site 570.

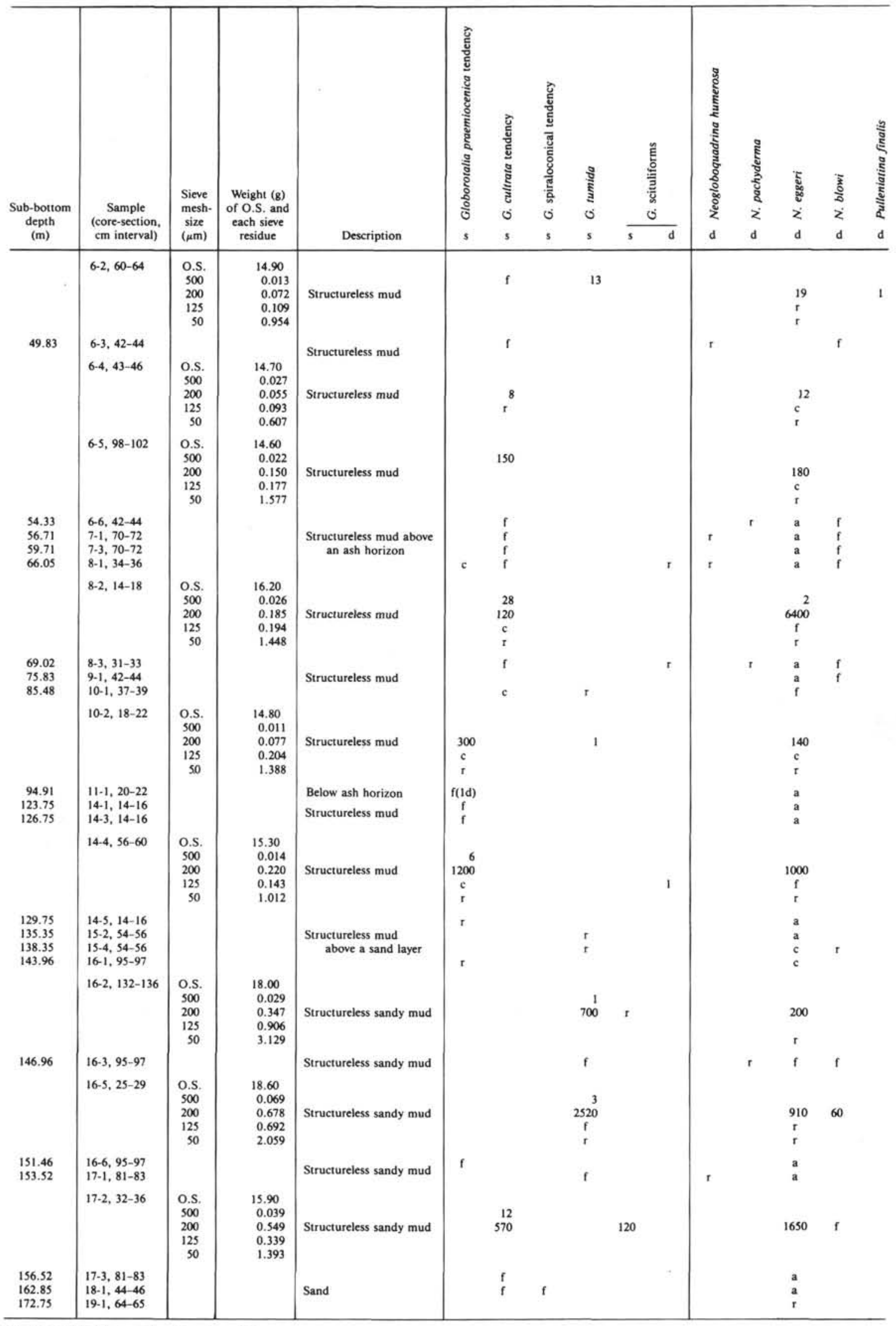

Note: See Table 2 for an explanation of symbols. 
UPPER OLIGOCENE TO RECENT PLANKTONIC FORAMINIFERS

Table 3. (Continued).

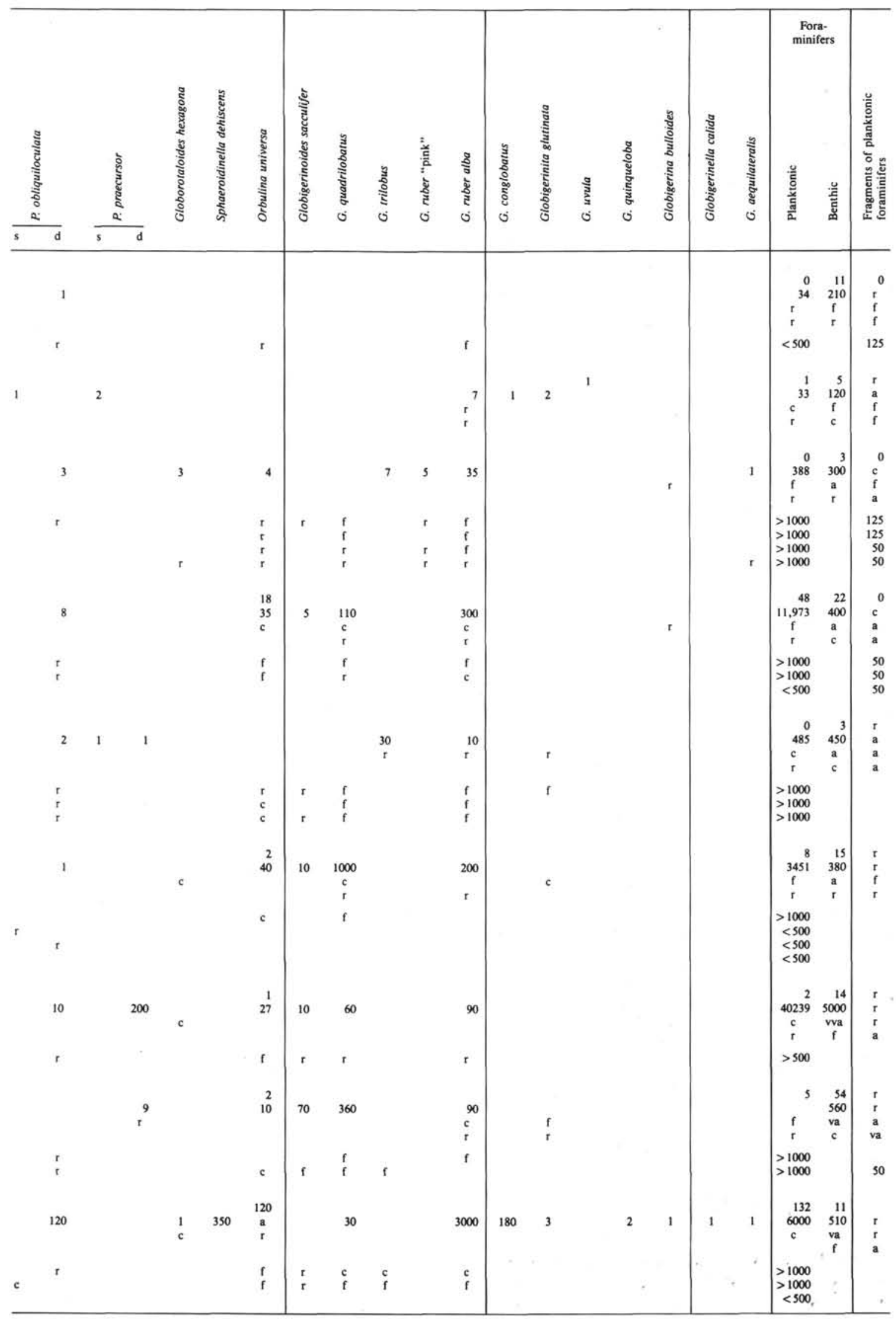

483 


\section{G. GLAÇON, J. BOURGOIS}

Table 4. Distribution of foraminifers at Site 570.

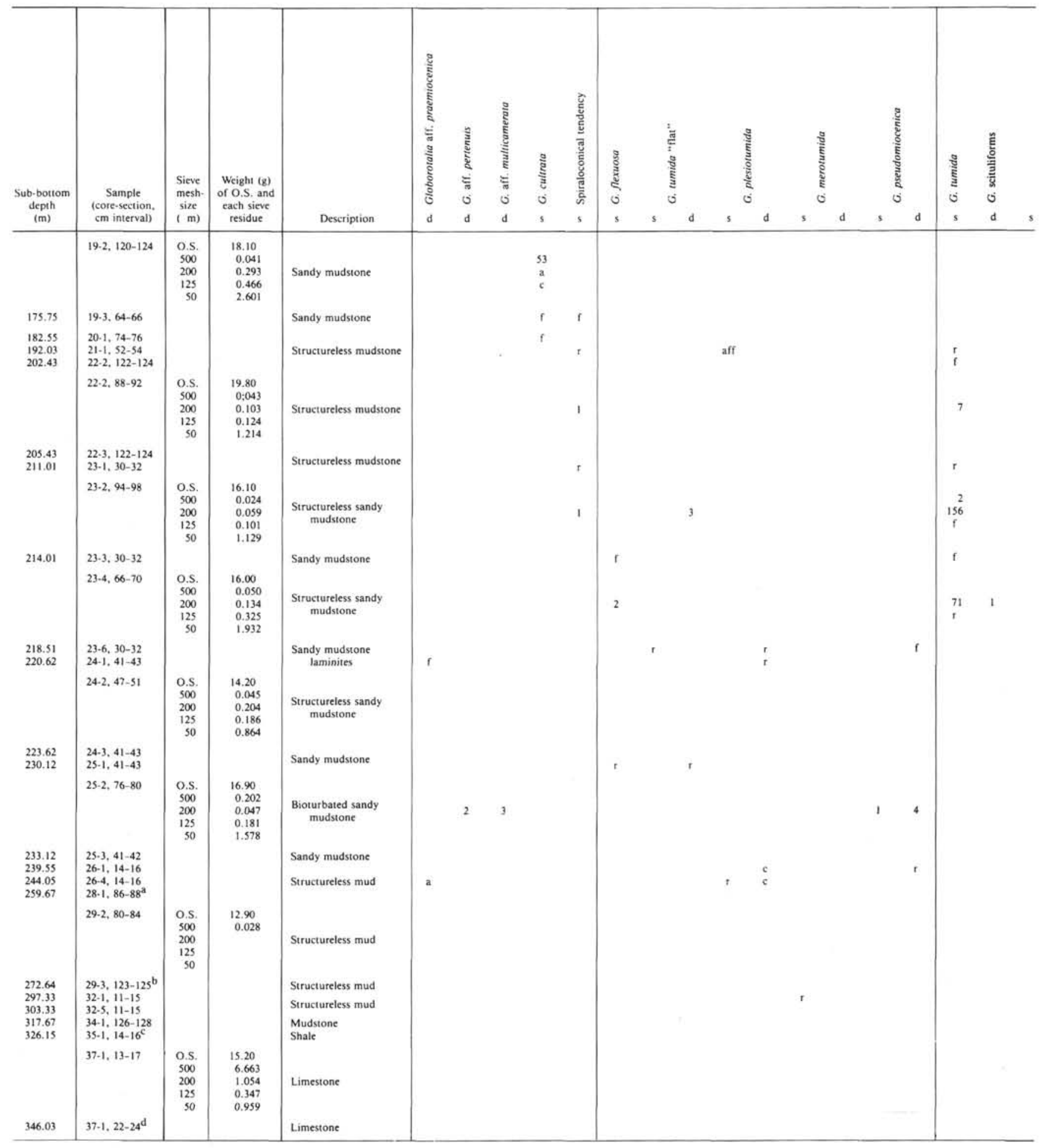

Note: See Table 2 for explanation of symbols.

a Also examined: $28-3,101-102 ; 28-6,107-109 ; 29.1,123-125$

b Also examined: 30-1, 20-22; 30-4, 20-22; 31-1, 117-119.

d Also examined: $38-1,77-79 ; 39-1,87-89$ (shale scaly fabric).

$\mathrm{cm}$ and $568-41-4,82-84 \mathrm{~cm}$; (2) Catapsydrax stainforthi, which occurs from Sample $568-40-2,45-48 \mathrm{~cm}$ to 568 $41-5,132-136 \mathrm{~cm}$, in sections dated $\mathrm{CN} 3$ by Filewicz (this volume) (we suspect that it is reworked, especially in view of the $70^{\circ}$ dip observed at that level); (3) Cata- psydrax dissimilis, which occurs from Sample 568-44-4, 62-66 cm to Sample 568-41-4, 82-84 cm, and C. unicavus, from Sample $568-40-5,70-74 \mathrm{~cm}$ to $568-35-2$, $86-90 \mathrm{~cm}$ (because Core $568-38$ is assigned to Nannozone $\mathrm{CN} 4$, some reworking is possible here). 
Table 4. (Continued).

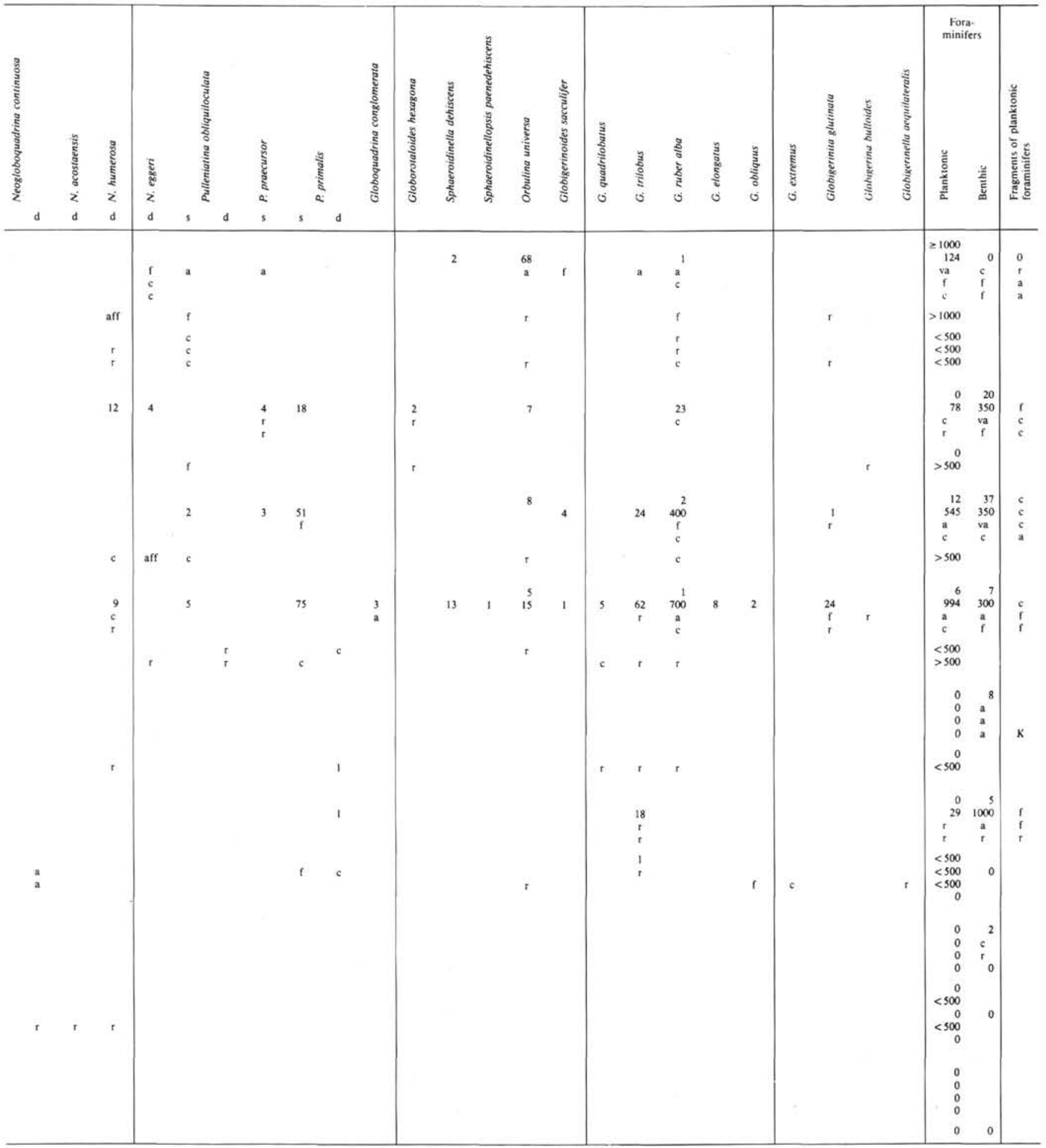

It thus appears that dissolution and sediment displacements preclude a detailed foraminiferal phyletic study at this site.

\section{Site 569}

Site 569 is located between Sites 568 and 567 on the landward side of the Middle America Trench at a water depth of $2799 \mathrm{~m}$ (Fig. 6, Table 12).
As expected, the section at this site is more condensed than at the other ones for the Pliocene-Quaternary, but the Oligocene-Miocene section is relatively more developed and more siliceous.

No pink Globigerinoides ruber nor Globigerinella calida occurs. The only coiling change in Pulleniatina obliquiloculata occurs in Core 569-5 a little below an acme of Globoquadrina conglomerata, suggesting that it cor- 


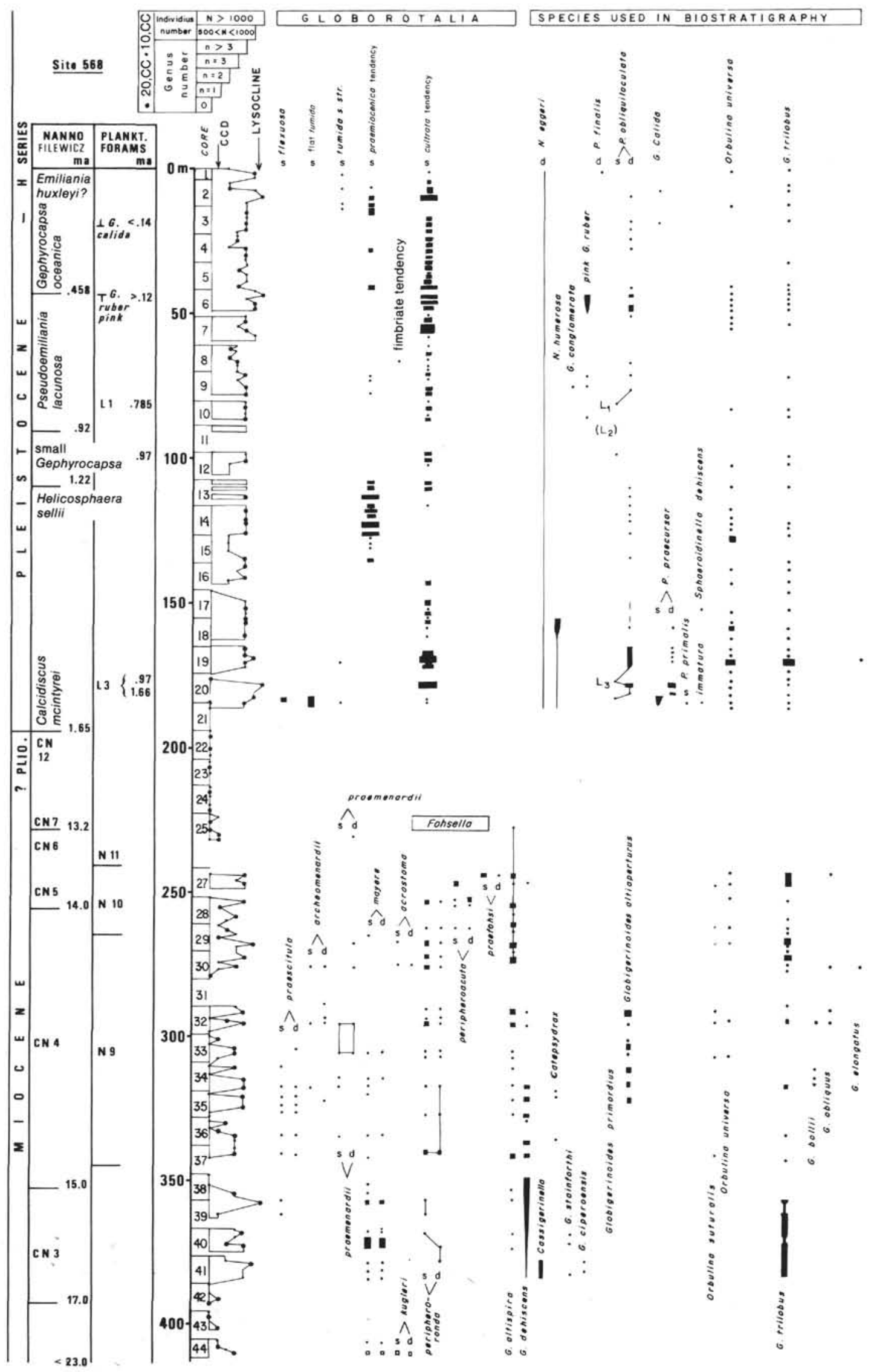

Figure 5. Biostratigraphic summary of Site 568 (see Fig. 4). 
responds to the peak $\mathrm{L}_{1}$ at about $0.785 \mathrm{Ma}$. This assumption is consistent with nannofossil data, which indicate an age of $0.458 \mathrm{Ma}$ close to the boundary of Cores 569-4 and -5 .

Based on nannofossil data, it appears that neither the disappearance of Neogloboquadrina humerosa nor that of Pulleniatina primalis can be used here as biostratigraphic datums but is rather a result of dissolution. That is true also of the appearance of Orbulina suturalis, which could be a dissolution-controlled event.

A number of Globorotaliids was found at Site 569. These forms belong to the "pitted" Globorotalia of McGowran (1968) or Paragloborotalia Cifelli (1982) or Jenkinsella Srinivasan and Kennett. They compare well with forms of the mayeri plexus sensu Bolli and Saunders (1982). Some are early Neogloboquadrina continuosa (Sample 569-27-1, 36-38 cm).

Fohsella are only represented by $F$. peripheroronda in Samples 569-13-2, 40-42 cm and 569-11-1, 40-42 cm. In the latter sample this species is associated with Globorotalia praescitula. In the tropics Srinivasan and Kennett (1981) found the same association dated between about 15 and $17 \mathrm{Ma}$, an age in agreement with the Helicosphaera ampliaperta Zone identified here between Sample 569-11-2, $71 \mathrm{~cm}$ and 569-12,CC.

A hiatus of about 12 m.y. occurs between Cores 569-10 and 569-8, above which G. praemiocenica first appears in association with left-coiling Pulleniatina primalis in Sample 569-8-1, 29-30 cm. Left-coiling P. obliquiloculata appears just slightly above in Sample 569$7-6,30-32 \mathrm{~cm}$ in association with the first Neogloboquadrina eggeri within the Discoaster pentaradiatus Subzone (2-2.1 Ma).

\section{Hole 567A}

Hole 567A, located at the base of the lower slope of the Middle America Trench at a water depth of $5529 \mathrm{~m}$, is the deepest hole at the west end of the Guatemala transect. The upper $176 \mathrm{~m}$ of Pleistocene have been washed from the top of this hole. Two samples from the first core dated early Pliocene by nannofossils are barren of planktonic foraminifers. Below these levels some dissolution-resistant planktonic foraminifers occur sporadically, always in small numbers, as follows.

Sample 567A-2-5, 5-67 cm. In this sample rare $\mathrm{NeO}-$ globoquadrina humerosa with fragments of Globigerinoides shells occur; this level is assigned to the Amaurolithus tricorniculatus Zone by Filewicz (this volume).

Sample 567A-3-6, 105-107 cm. Globoquadrina praedehiscens and $G$. dehiscens with rare Globigerinoides bisphericus and minuscule Paragloborotalia sp. are present here. This association suggests a zonal assignment to the upper part of N7 Blow, in agreement with the nannofossil Helicosphaera ampliaperta Zone.

Sample 567A-6-2, 106-108 cm. Globoquadrina venezuelana, with Globigerinoides bisphericus, occur in this sample. Below this level, from Sample 567A-8-1, 56-58 $\mathrm{cm}$ to $567 \mathrm{~A}-10-1,74-76 \mathrm{~cm}$ Globigerinoides bisphericus still occurs. Filewicz (this volume) assigns these samples and the interval below, down to 567A-13, CC, to the $\mathrm{He}$ licosphaera ampliaperta Zone.
Sample $567 A-10-1,74-76 \mathrm{~cm}$. This is an example of downhole contamination with sinistral Pulleniatina and molds of Globorotalia.

\section{Site 565}

Site 565 is located on the lower slope of the landward side of the Middle America Trench off Costa Rica at a water depth of $3111 \mathrm{~m}$ (Fig. 7).

Samples at this site appear to be always located below the planktonic foraminiferal lysocline and commonly below the CCD. But it is not easy to identify in situ from gravity-reworked samples, for no shallower site off Costa Rica is available for comparison as was the case in the area off Guatemala. Yet we are able to recognize differences between the faunal assemblages of the two geographic areas. Here, very often, the last species to remain belongs to the genus Globorotalia instead of Globoquadrina or Neogloboquadrina. Strongly encrusted Globorotalia inflata occur in core Sample 565-1-7, 10$14 \mathrm{~cm}$. Some specimens with only three chambers at the last whorl resemble $G$. triangula Theyer, although there is a slight difference in the vaulting of the umbilical face. G. triangula is reported from the uppermost Pliocene and middle Pleistocene of the Tasman Sea; these forms slightly resemble some three-chambered morphotypes of the G. puncticulata group from Mediterranean Pliocene.

The co-occurrence of pink Globigerinoides ruber with Globigerinella calida in Sample 565-1-1, 32-36 cm indicates an age of $0.12-0.14 \mathrm{Ma}$.

Planktonic foraminifers often appear to be reworked at Site 565, as shown by the occurrence of Pulleniatina primalis and $P$. praecursor above the stratigraphic range. Left-coiled P. obliquiloculata are found in the Gephyrocapsa oceanica Zone $(0.268-0.458 \mathrm{Ma})$, whereas the last sinistral $P$. obliquiloculata is dated $0.785 \mathrm{Ma}$ (see Fig. 2). Reworking could explain the stratigraphically too-high sporadic occurrence of "flat" Globorotalia tumida in Core 565-7 in the Gephyrocapsa oceanica Zone; this species is usually found in the lower Pliocene.

Upper Miocene, small-keeled "C"-type chambered, randomly coiled Globorotalia menardii occur with some randomly coiled $G$. merotumida in Core 565-34. Above this level, dissolution precludes a detailed study. Specimens of dextral Globorotalia, about twice as large as the previous ones found in Core 565-34, appear abruptly in Core 565-31. Generally biconvex, they compare well with $G$. praemiocenica. A few of them show a weak tendency toward a flattening of the spiral face, but never as pronounced as in G. miocenica sensu stricto. Other ones show a tendency to increase the number of chambers of the last whorl; the chambers become therefore more radially elongated, the thinner walled resemble $G$. pertenuis, but none of them is identical to the type of that species. The thicker-walled forms with strongly limbate sutures compare well with $G$. multicamerata.

In Sample 565-30-5, 102-107 cm, there are some Globorotalia tumida with a flat umbilical face reminiscent of $G$. plesiotumida but three times as large as the latter. Most specimens are dextral but a few, with a weak flexuosa tendency, are sinistral. Above this level all these 
Table 5. Distribution of foraminifers at Site 568.

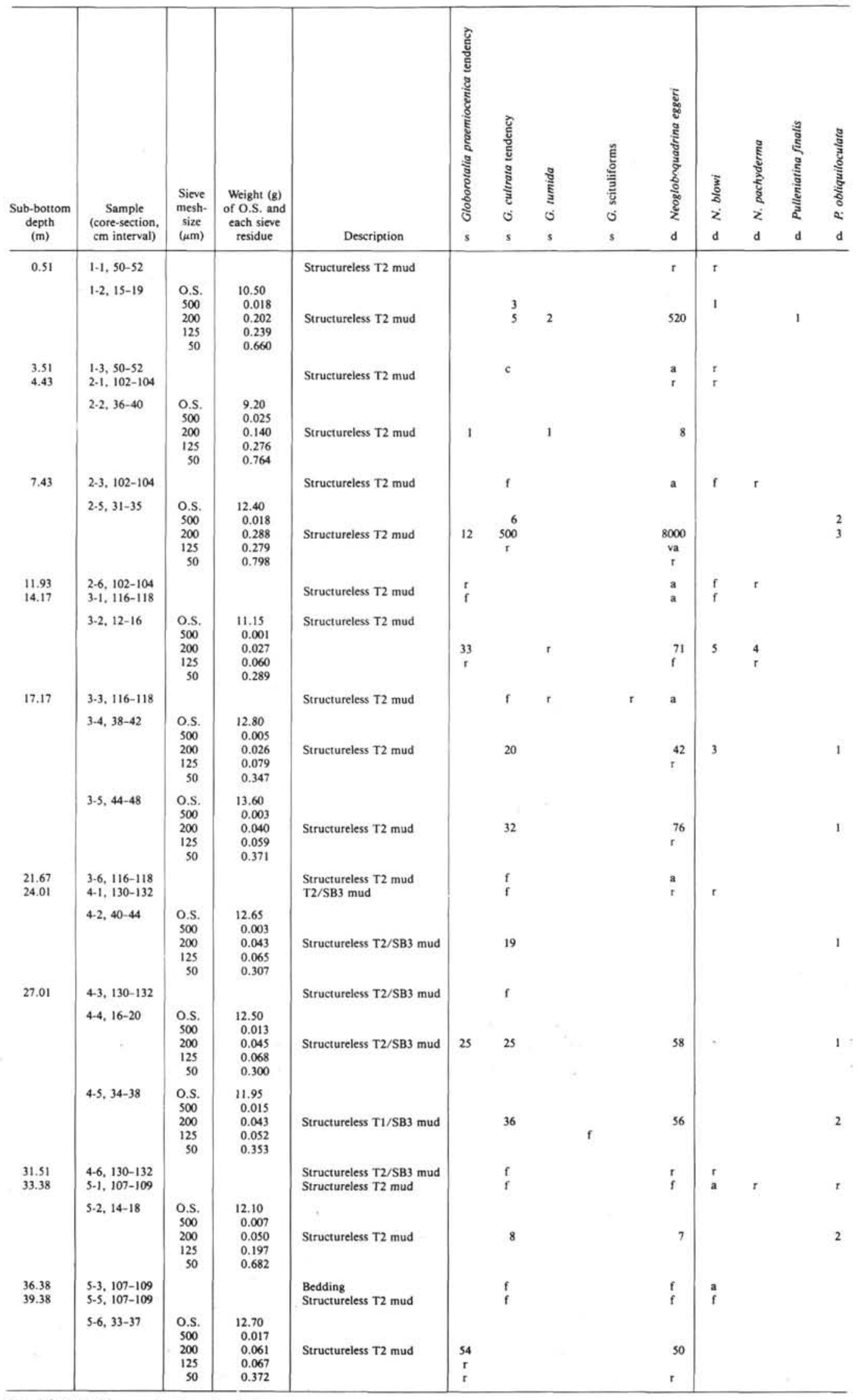

Note: See Table 2 for an explanation of symbols. 
Table 5. (Continued).

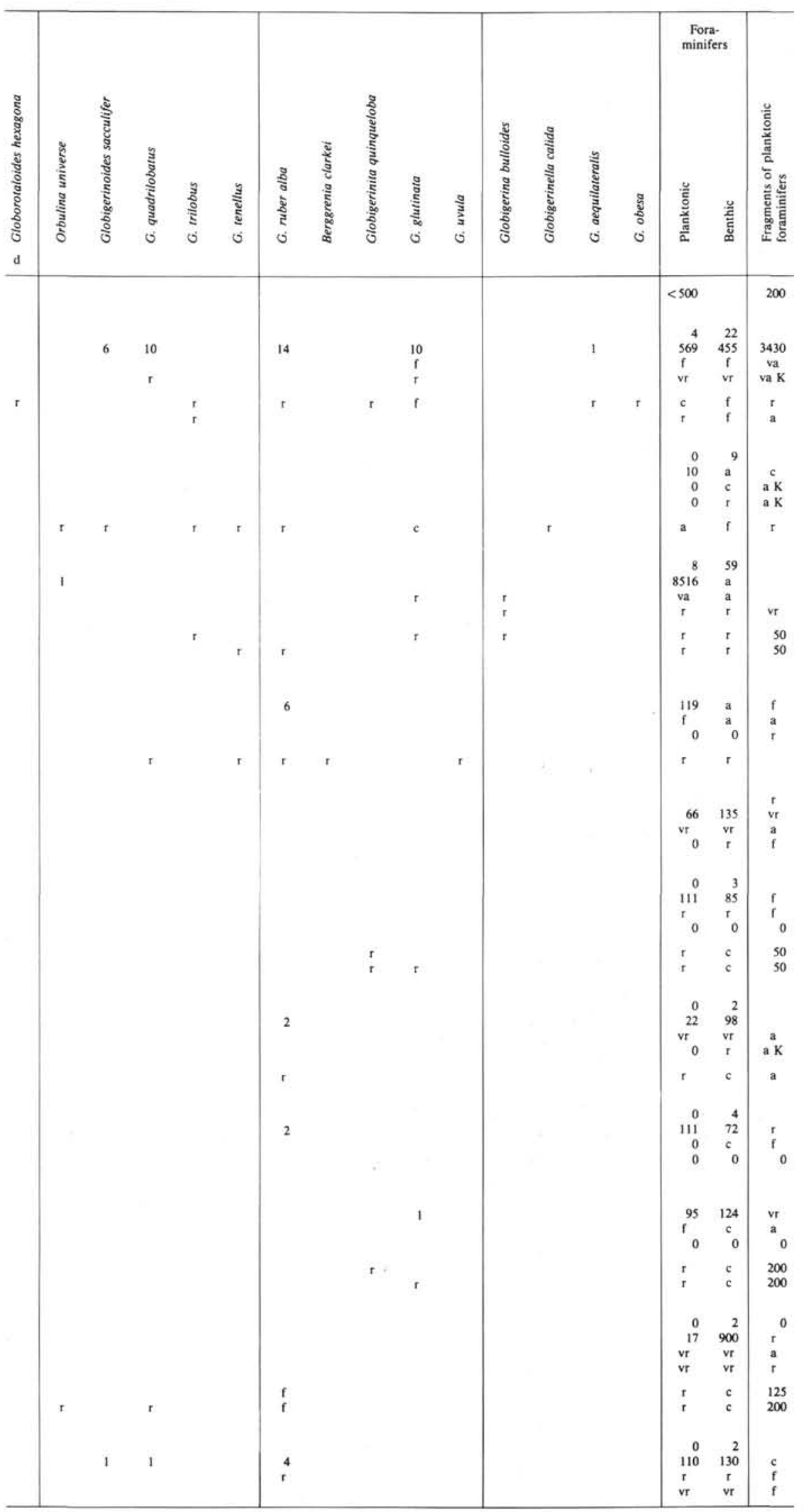


Table 6. Distribution of foraminifers at Site 568.

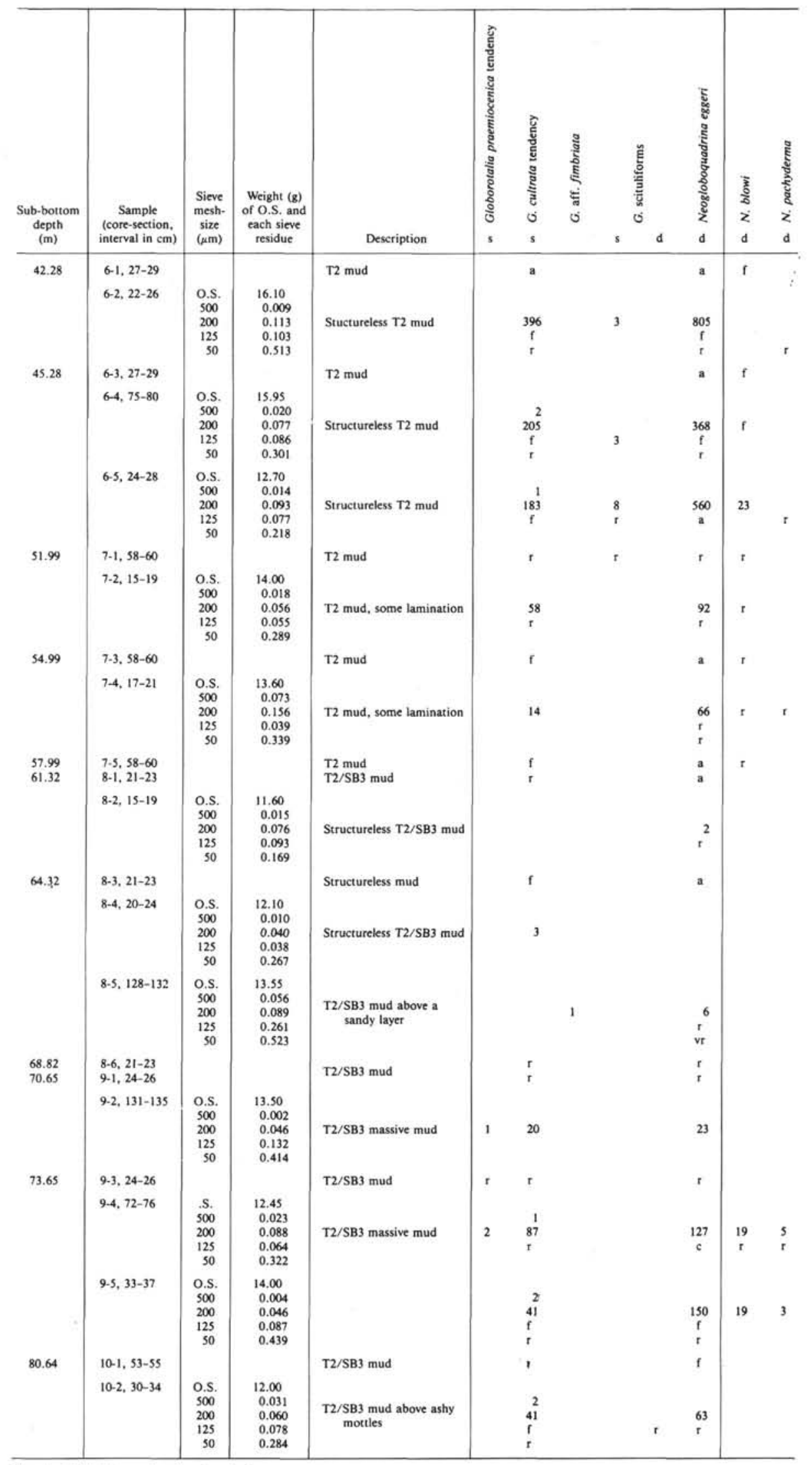

Note: See Table 2 for explanation of symbols. 
Table 6. (Continued).

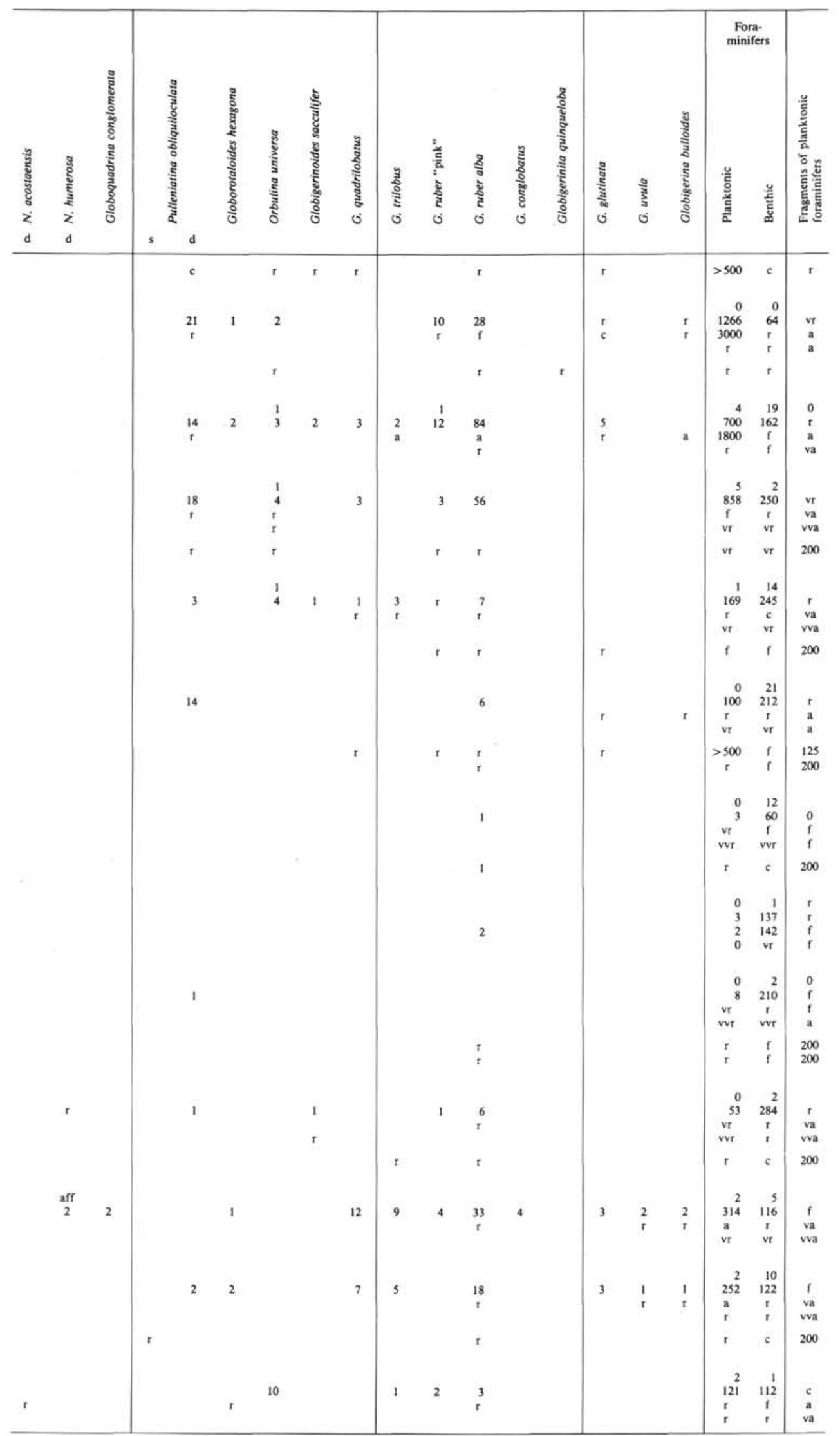


Table 7. Distribution of foraminifers at Site 568.

\begin{tabular}{|c|c|c|c|c|c|c|c|c|c|c|c|c|}
\hline $\begin{array}{l}\text { Sub-bottom } \\
\text { depth } \\
\text { (m) }\end{array}$ & $\begin{array}{c}\text { Sample } \\
\text { (core-section, } \\
\text { interval in } \mathrm{cm} \text { ) }\end{array}$ & $\begin{array}{l}\text { Sieve } \\
\text { mesh- } \\
\text { size } \\
(\mu \mathrm{m})\end{array}$ & $\begin{array}{l}\text { Weight (g) } \\
\text { of O.S. and } \\
\text { each sieve } \\
\text { residue }\end{array}$ & Description & 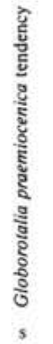 & 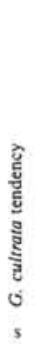 & $s$ & d & 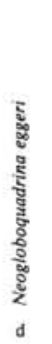 & $\begin{array}{l}\frac{7}{3} \\
\frac{1}{b} \\
z \\
\text { d }\end{array}$ & 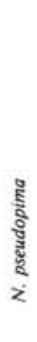 & $\begin{array}{l}\text { के } \\
\text { है } \\
\text { है } \\
\text { ç } \\
\text { z } \\
\mathrm{d}\end{array}$ \\
\hline 83.64 & $10-3,53-55$ & & & $\mathrm{~T} 2 / \mathrm{SB} 3 \mathrm{mud}$ & & $t$ & & & $r$ & & & \\
\hline & $10-4,118-122$ & $\begin{array}{r}0.5 \\
500 \\
200 \\
125 \\
50\end{array}$ & $\begin{array}{c}12.70 \\
0.009 \\
0.230 \\
0.138 \\
0.384\end{array}$ & $\mathrm{~T} 2 / \mathrm{SB} 3 \mathrm{mud}$ & & $\begin{array}{r}11 \\
4 \\
r\end{array}$ & & & $\begin{array}{r}18 \\
5 \\
5\end{array}$ & 1 & & \\
\hline 99.46 & $\begin{array}{l}12-1,65-67 \\
12-2,108-112\end{array}$ & $\begin{array}{r}0 . S . \\
500 \\
200 \\
125 \\
50\end{array}$ & $\begin{array}{c}13.70 \\
0.014 \\
0.089 \\
0.085 \\
0.198\end{array}$ & $\begin{array}{l}\text { T2/SB3 mud } \\
\text { T2/SB3 mud }\end{array}$ & & $\begin{array}{c}28 \\
\mathrm{r}\end{array}$ & $\mathrm{r}$ & & $\underset{f}{123}$ & r & & aff \\
\hline $\begin{array}{l}102.46 \\
109.61 \\
111.78\end{array}$ & $\begin{array}{l}12-3,65-67 \\
13-1,130-132 \\
13-3,47-49\end{array}$ & & & $\mathrm{~T} 2 / \mathrm{SB} 3 \mathrm{mud}$ & f & $\begin{array}{l}\mathrm{t} \\
\mathrm{f} \\
\mathrm{f}\end{array}$ & & & $\begin{array}{l}r \\
\mathrm{a} \\
\mathrm{a}\end{array}$ & $\begin{array}{l}\mathrm{r} \\
\mathrm{f} \\
\mathrm{f}\end{array}$ & & $\begin{array}{l}\text { aff } \\
\text { aff }\end{array}$ \\
\hline & $13-5,14-18$ & $\begin{array}{r}0 . S . \\
500 \\
200 \\
125 \\
50\end{array}$ & $\begin{array}{c}17.60 \\
0.015 \\
0.098 \\
0.163 \\
0.536\end{array}$ & $\mathrm{~T} 2 / \mathrm{SB} 3 \mathrm{mud}$ & $\begin{array}{c}1 \\
393 \\
\mathrm{c} \\
\mathrm{r}\end{array}$ & & & $\mathrm{r}$ & $\begin{array}{c}460 \\
\mathrm{c} \\
\mathrm{t}\end{array}$ & $\begin{array}{l}12 \\
r\end{array}$ & & \\
\hline 117.96 & $\begin{array}{l}14-1,15-17 \\
14-2,68-72\end{array}$ & $\begin{array}{l}\text { O.S. } \\
500 \\
200 \\
125 \\
50\end{array}$ & $\begin{array}{c}15.05 \\
0.002 \\
0.033 \\
0.086 \\
0.364\end{array}$ & $\begin{array}{l}\text { T2/SB3 mud } \\
\text { T2/SB3 weakly } \\
\text { stratified mud }\end{array}$ & $\begin{array}{c}198 \\
f \\
r\end{array}$ & $t$ & & & $\begin{array}{l}18 \\
f \\
c\end{array}$ & $f$ & & $t$ \\
\hline 120.96 & $\begin{array}{l}14-3,15-17 \\
14-4,70-74\end{array}$ & $\begin{array}{r}\text { O.S. } \\
500 \\
200 \\
125 \\
50\end{array}$ & $\begin{array}{l}16.60 \\
0.021 \\
0.115 \\
0.120 \\
0.425\end{array}$ & $\begin{array}{l}\mathrm{T} 2 / \mathrm{SB} 3 \mathrm{mud} \\
\mathrm{T} 2 / \mathrm{SB} 3 \mathrm{mud}\end{array}$ & $\begin{array}{c}296 \\
\mathrm{c} \\
\mathrm{r}\end{array}$ & & & & $\begin{array}{c}182 \\
c \\
t\end{array}$ & $f$ & 3 & a \\
\hline 125.38 & $\begin{array}{l}14-6.7-9 \\
14-7,35-38\end{array}$ & $\begin{array}{l}\text { O.S. } \\
500 \\
200 \\
125 \\
50\end{array}$ & $\begin{array}{c}14.50 \\
0.022 \\
0.074 \\
0.067 \\
0.433\end{array}$ & $\begin{array}{l}\text { T2/SB3 mud } \\
\text { T2/SB3 weakly } \\
\text { stratified mud }\end{array}$ & $\begin{array}{c}253 \\
f \\
t\end{array}$ & & & & a & $r$ & 32 & $t$ \\
\hline $\begin{array}{l}127.50 \\
130.48 \\
133.48\end{array}$ & $\begin{array}{l}15-1,9-11 \\
15-3,7-9 \\
15-5,7-9\end{array}$ & & & $\begin{array}{l}\text { T2/SB3 mud } \\
\text { Soupy mud }\end{array}$ & $\begin{array}{l}\mathrm{r} \\
\mathrm{r} \\
\mathrm{r}\end{array}$ & & & & $\begin{array}{l}t \\
t \\
f\end{array}$ & & & \\
\hline & $15-6,12-16$ & $\begin{array}{l}\text { O.S. } \\
500 \\
200 \\
125 \\
50\end{array}$ & $\begin{array}{l}15.30 \\
0.035 \\
0.130 \\
0.202 \\
0.444\end{array}$ & $\mathrm{~T} 2 / \mathrm{SB} 3$ mud & $\begin{array}{l}56 \\
r \\
r\end{array}$ & & & & & & $\frac{12}{r}$ & \\
\hline & $16-1,131-135$ & $\begin{array}{r}0.5 \\
500 \\
200 \\
125 \\
50\end{array}$ & $\begin{array}{c}14.90 \\
0.052 \\
0.090 \\
0.223 \\
0.635\end{array}$ & T2 mud & $\begin{array}{c}1 \\
214 \\
r \\
r\end{array}$ & & & & $\begin{array}{c}112 \\
r \\
r\end{array}$ & & & \\
\hline 140.42 & $\begin{array}{l}16-3,21-23 \\
16-4,98-102\end{array}$ & $\begin{array}{l}0.5 . \\
500 \\
200 \\
125 \\
50\end{array}$ & $\begin{array}{c}16.10 \\
0.087 \\
0.081 \\
0.168 \\
0.375\end{array}$ & T2 mud & $\begin{array}{l}63 \\
r\end{array}$ & & 1 & & $\begin{array}{l}24 \\
\mathrm{r}\end{array}$ & & & \\
\hline $\begin{array}{l}143.39 \\
147.31 \\
150.31\end{array}$ & $\begin{array}{l}16-5,18-20 \\
17-1,40-42 \\
17-3,40-42\end{array}$ & & & T2 mud & $t$ & $\begin{array}{l}f \\
f\end{array}$ & & & $\begin{array}{l}t \\
t\end{array}$ & , & & \\
\hline & $17.5,102-106$ & $\begin{array}{l}\text { O.S. } \\
500 \\
200 \\
125 \\
50\end{array}$ & $\begin{array}{l}13.05 \\
0.035 \\
0.104 \\
0.099 \\
0.294\end{array}$ & T2 mud & & $\begin{array}{r}2 \\
43 \\
t\end{array}$ & & 1 & & & & \\
\hline 154.81 & $17-6,40-42$ & $\mathrm{~T} 2$ & mud & & & $t$ & & & $f$ & & & $\mathrm{t}$ \\
\hline & $18-1,123-127$ & $\begin{array}{l}\text { O.S. } \\
500 \\
200 \\
125 \\
50\end{array}$ & $\begin{array}{c}13.20 \\
0.088 \\
0.121 \\
0.084 \\
0.272\end{array}$ & Structureless $\mathrm{T} 2$ mud & & $\begin{array}{r}1 \\
14\end{array}$ & & & 5 & & & \\
\hline
\end{tabular}

Note: See Table 2 for an explanation of the symbols. 
Table 7. (Continued).

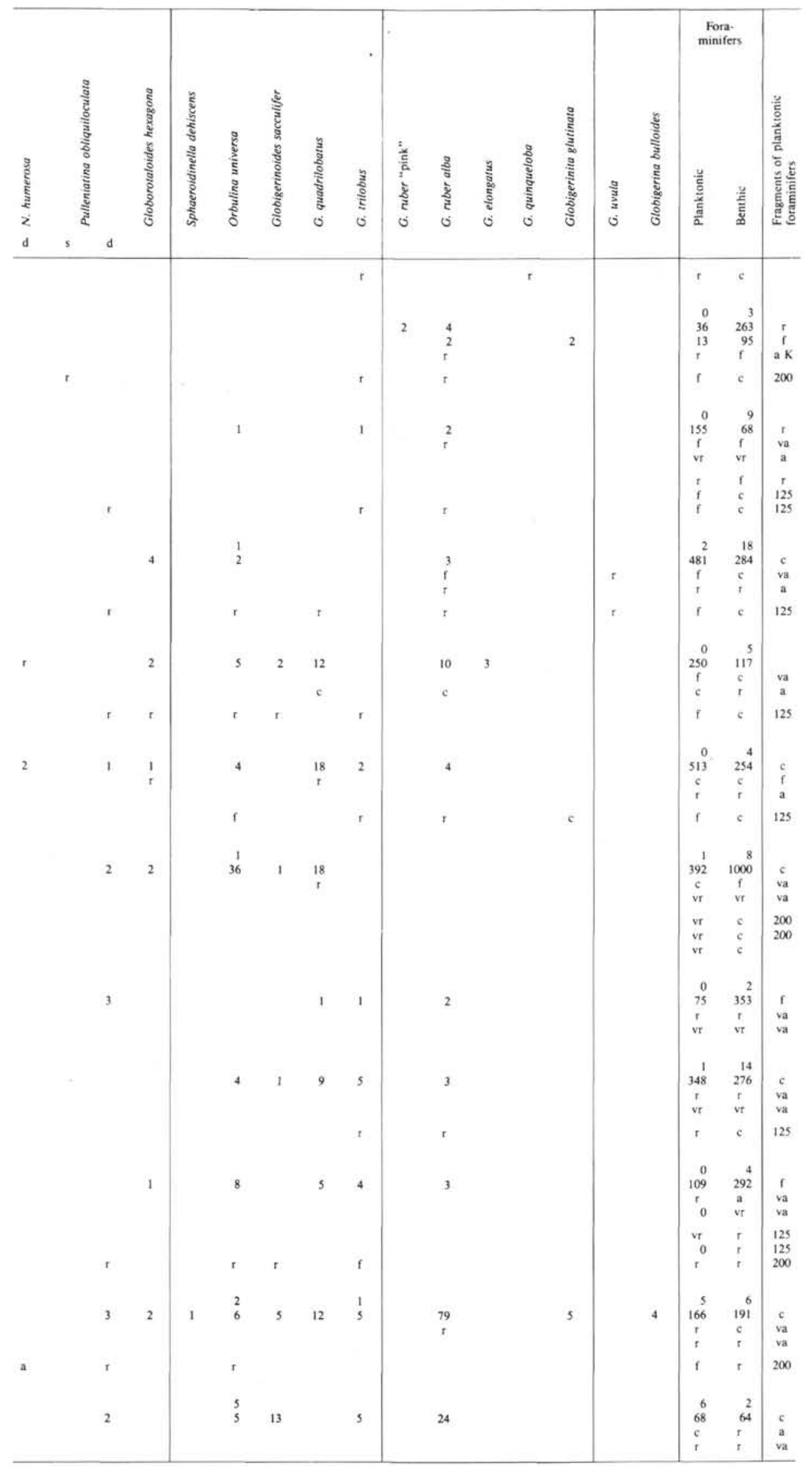


Table 8. Distribution of foraminifers at Site 568 .

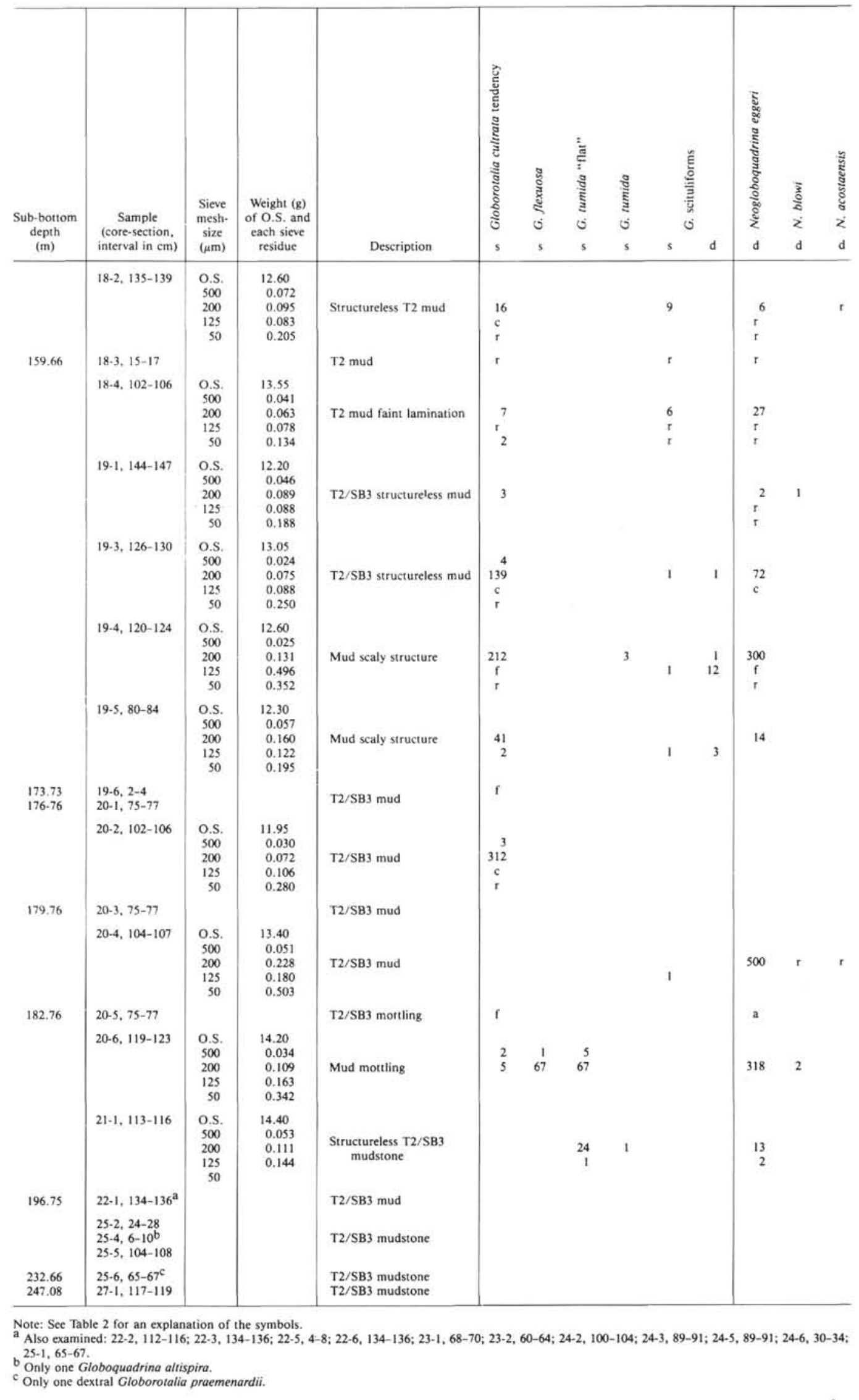


Table 8. (Continued).

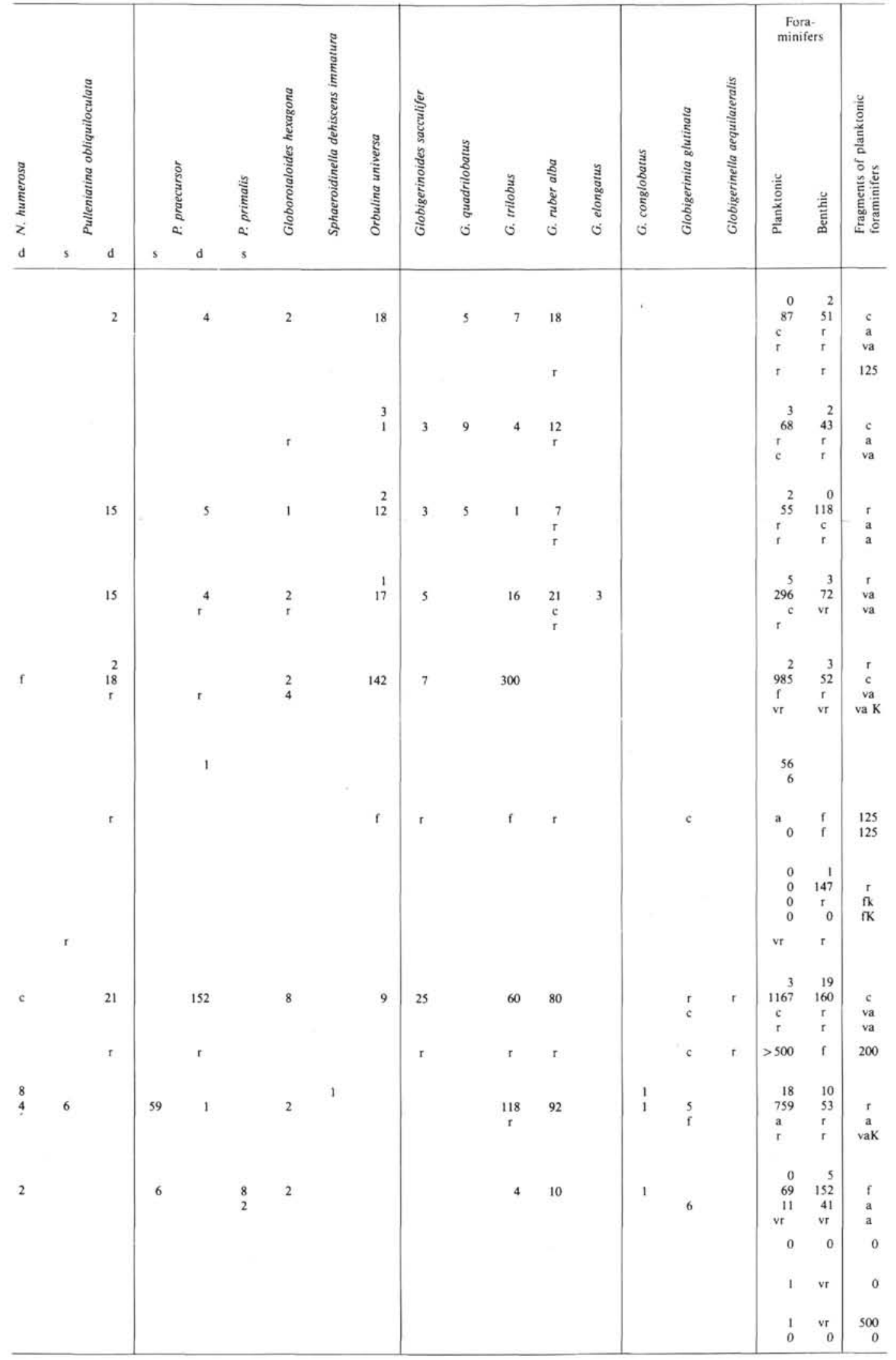


Table 9. Distribution of foraminifers at Site 568.

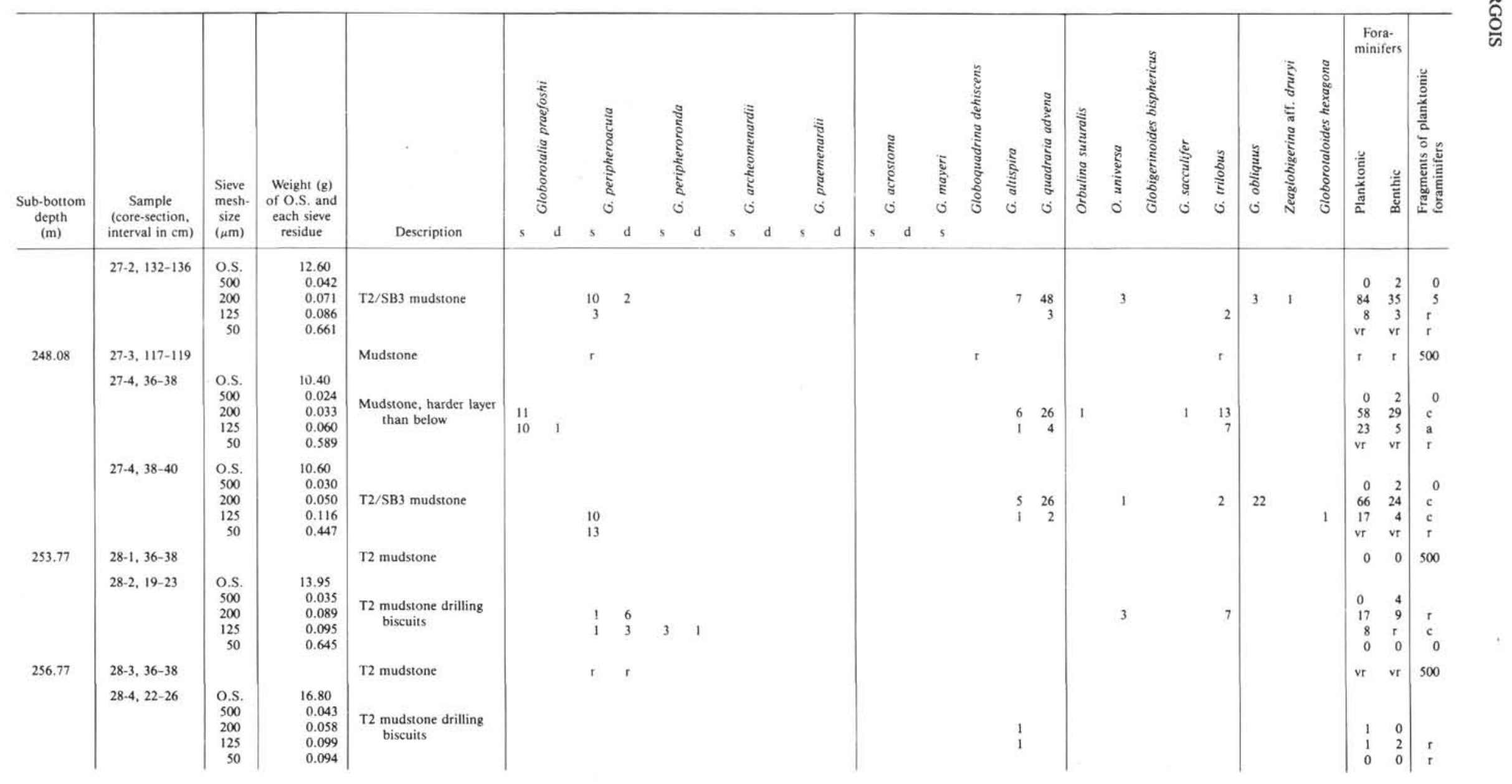




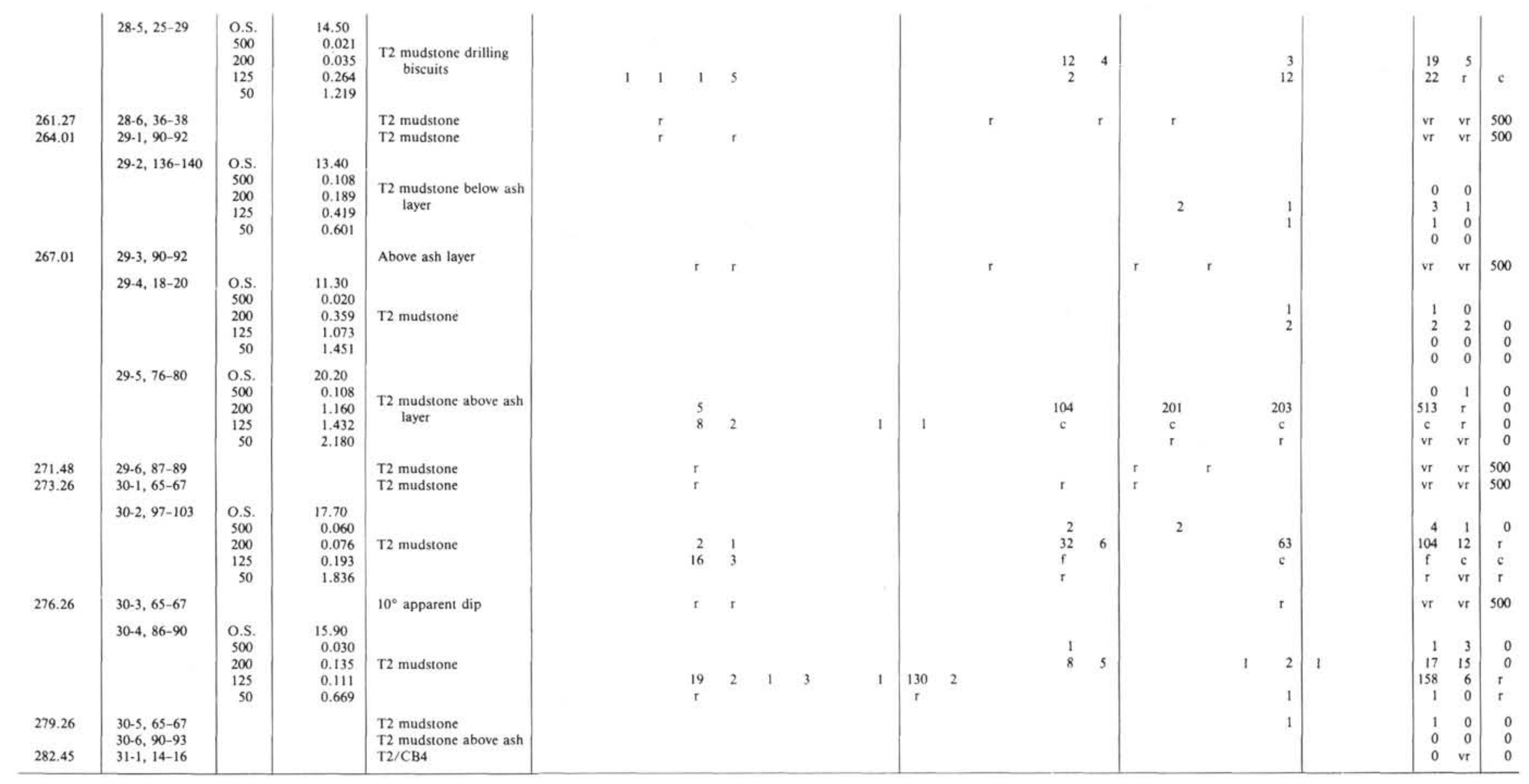

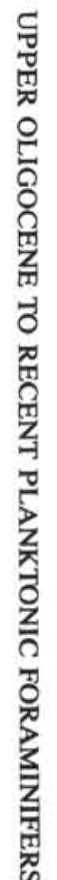


Table 10. Distribution of foraminifers at Site 568.

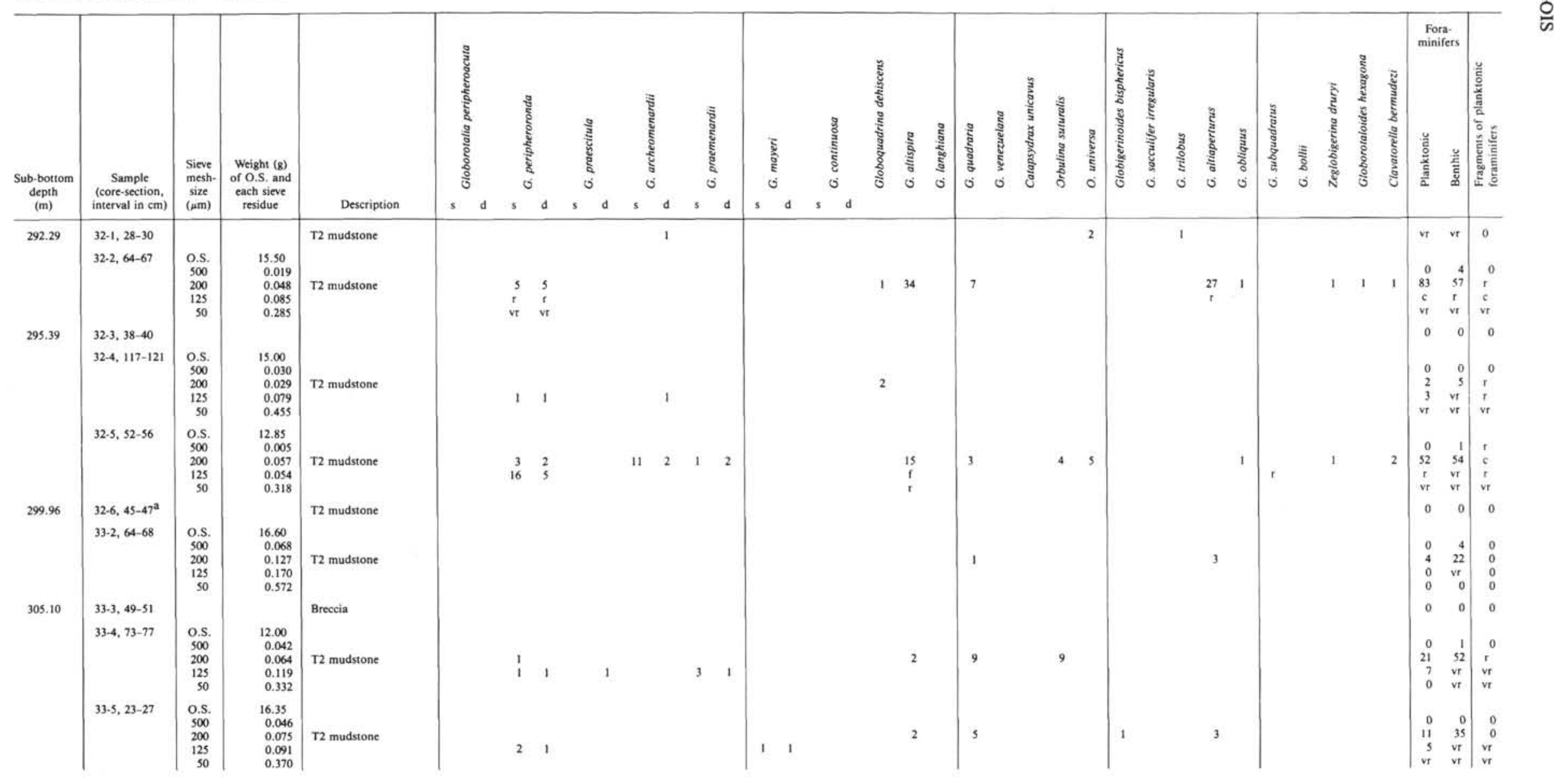




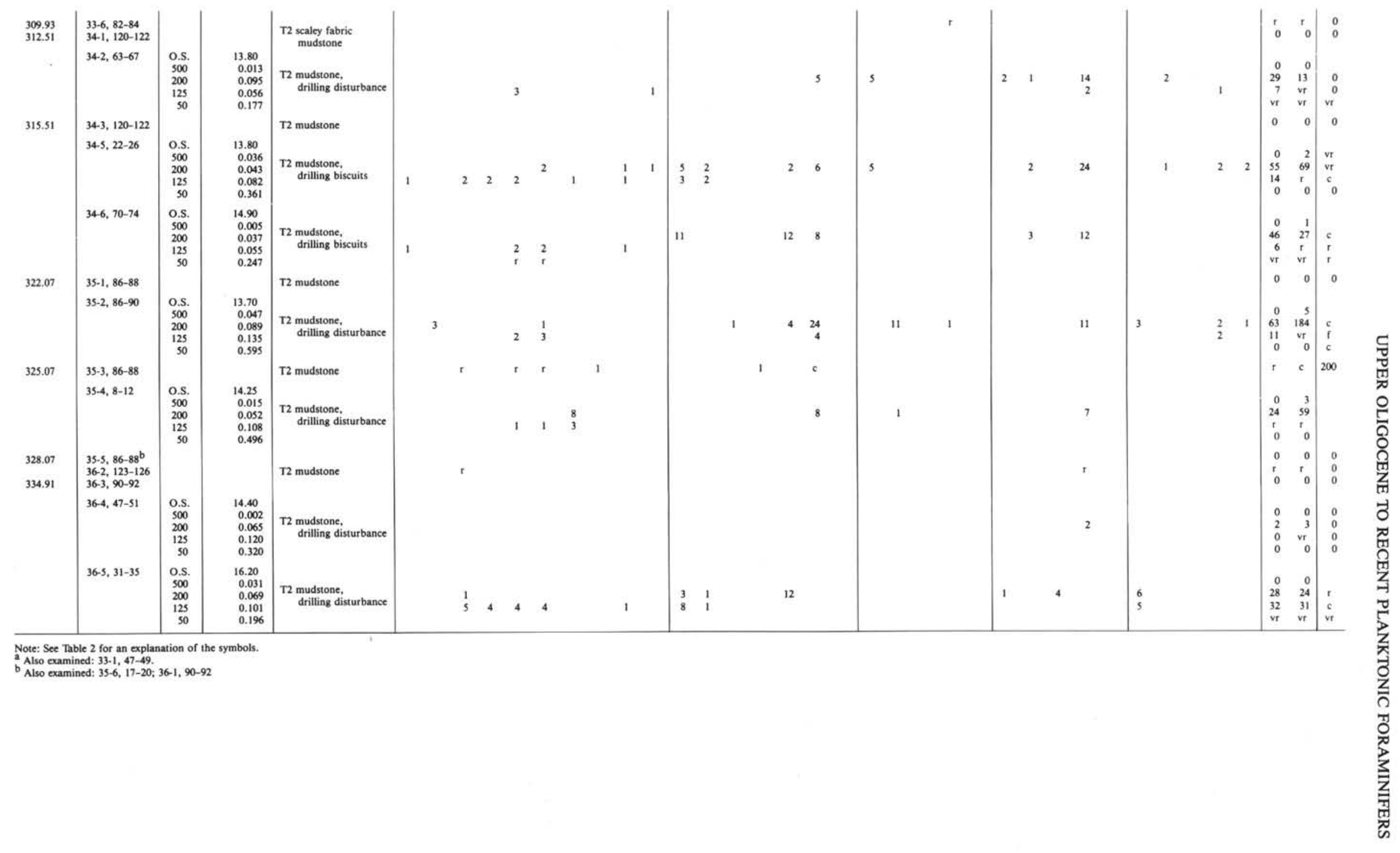




\section{G. GLAÇON, J. BOURGOIS}

Table 11. Distribution of foraminifers at Site 568 .

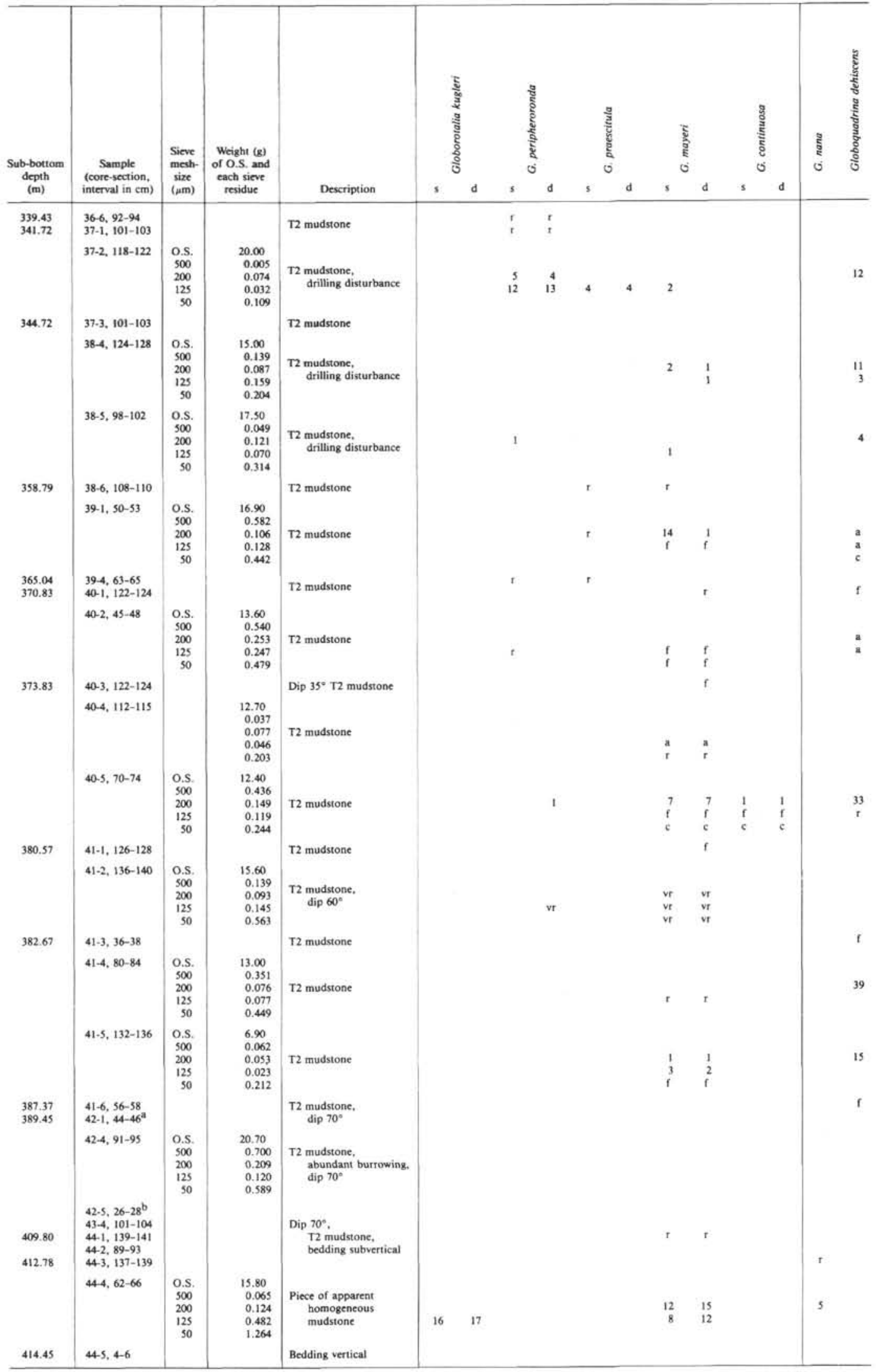

Note: See Table 2 for an explanation of the symbols. 
Table 11. (Continued).

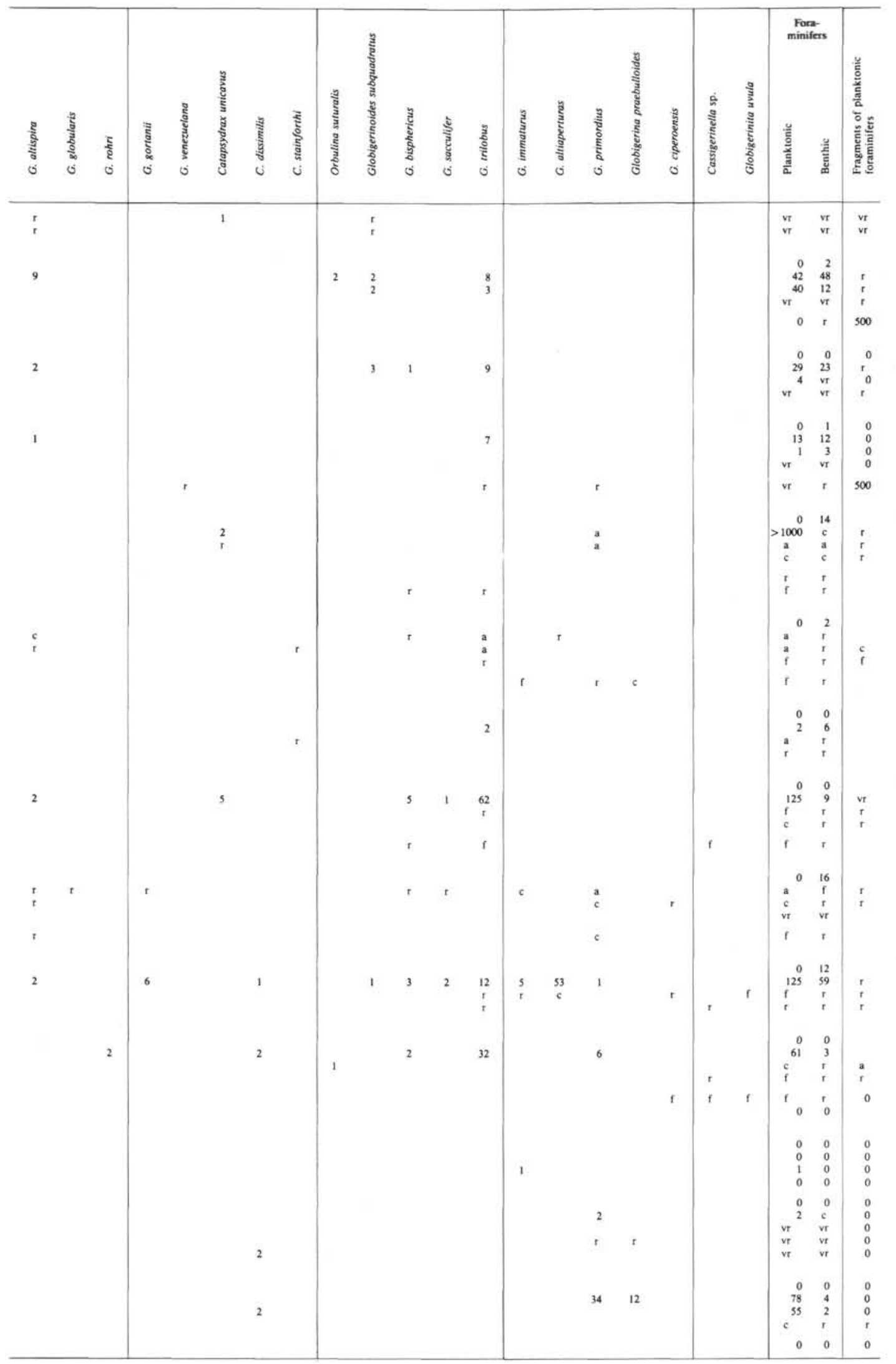




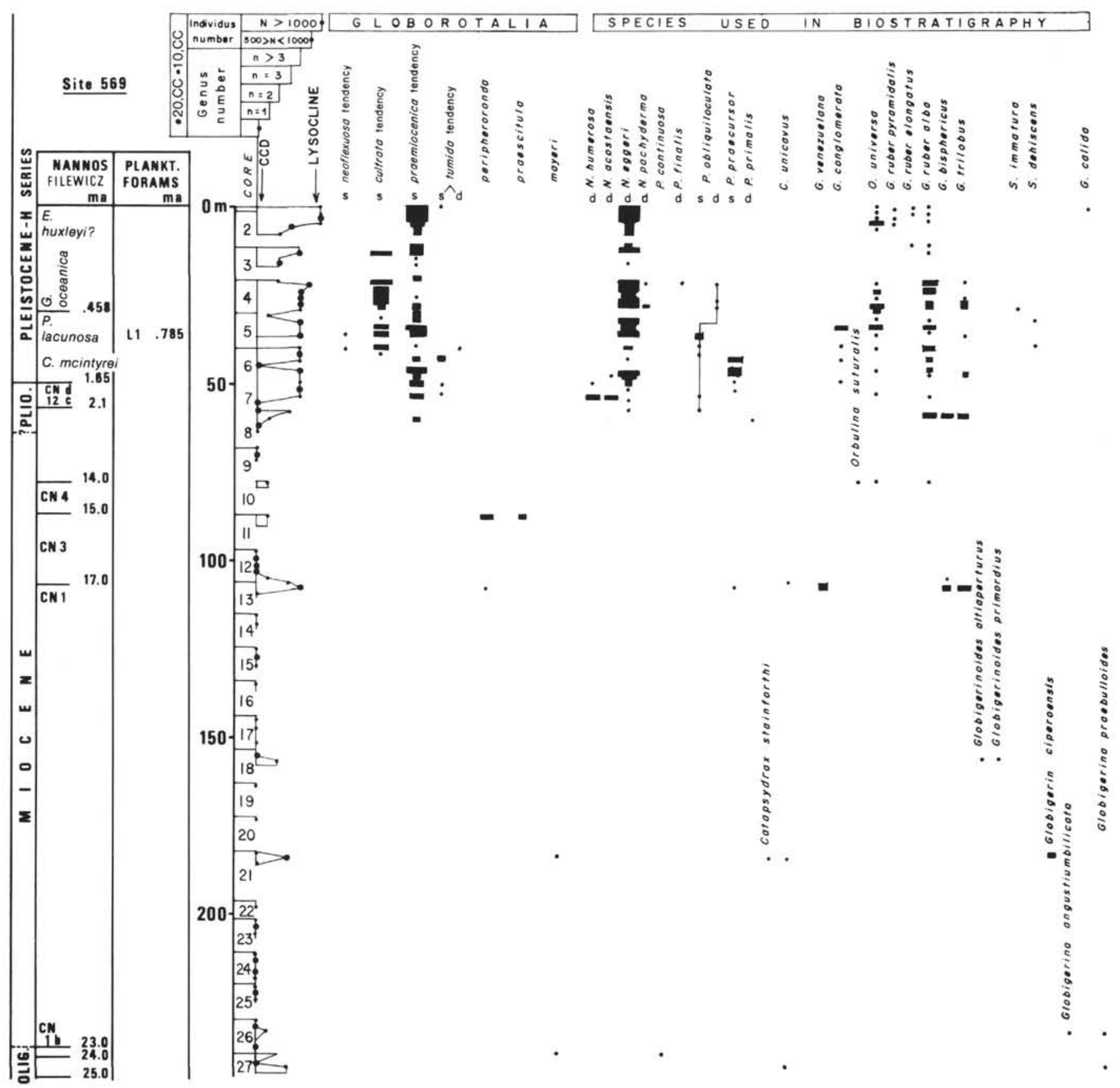

Figure 6. Biostratigraphic summary of Site 569 (see Fig. 4).

globorotaliids co-occur and change their coiling mode from dextral to sinistral at different levels: the "flat" $G$. tumida become sinistral in Sample 565-26-2, 138-141 cm, whereas G. praemiocenica and $G$. aff. pertenuis-multicamerata change simultaneously from left to right just above a level with strong dissolution in Sample 565$18-2,120-130 \mathrm{~cm}$. The level of disappearance of the $G$. aff. pertenuis group is in Core 565-16, and that of the "flat" G. tumida and G. flexuosa in Core 565-7.

\section{Summary of Biostratigraphic Results}

Planktonic foraminiferal biostratigraphic events are in good agreement with the nannofossil biozonation giv- en by Filewicz (this volume). Peaks of the coiling curves of Pulleniatina are good correlative tools, provided they are calibrated to another stratigraphic scale. We used here the nannofossil zonation for comparison (Fig. 8). Left-coiling peaks of Pulleniatina (see Figs. 2-8) allow correlations to be made between the various sites. They are identified as follows:

During the Pleistocene: $\mathrm{L}_{1}(0.758 \mathrm{Ma})$ at Site 570 (570-5-2, 85-90 cm, Site $568(568-10-1,53-55 \mathrm{~cm})$, and Site 569 (upper part of Core $569-5) ; \mathrm{L}_{2}(0.97 \mathrm{Ma}$ ) at Site 570 (570-6-4, 43-46 cm); $\mathrm{L}_{3}$ (between 0.97 and $1.66 \mathrm{Ma}$, following Hays et al. [1969], but here, taking in account the nannofossil zonation, the age should be between 
Table 12. Distribution of foraminifers at Site 569.

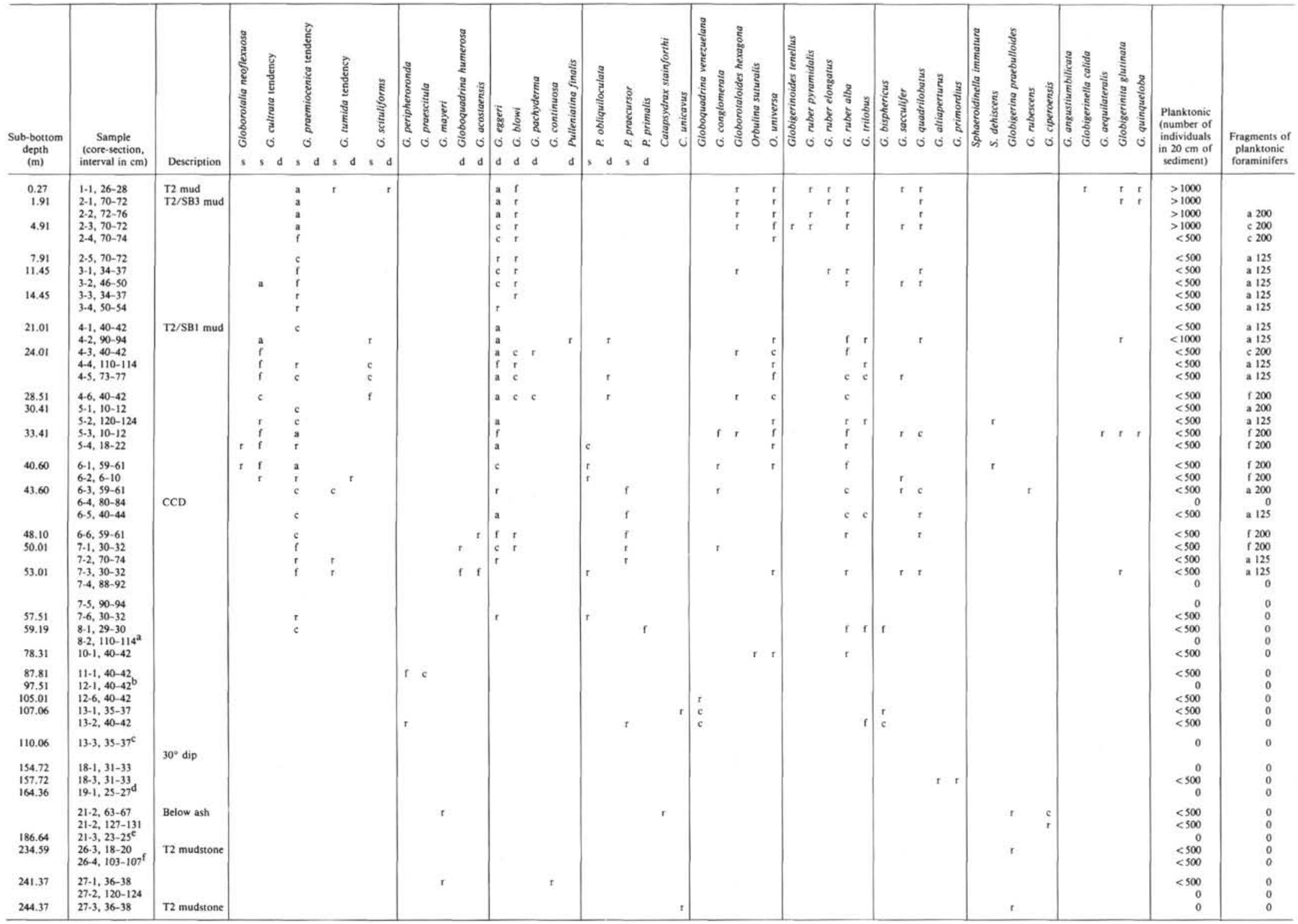

Note: See Table 2 for an explanation of the symbols.
a Also examined: $8-3,28-30 ; 9-1,30-32 ; 9-2,115-119$.

Also examined: $12-2,14-18,12-3,40-42,12-4,14-18 ; 12-5,125-128$

Also examined: $14-1,35-37$ : 14-3, 35-37: 15-1, 84-86; 15-2, 67-70; 15-3, 84-86; 16-1, 46-50; 16-1, 86-88: 17-1, 53-55: 17-6, 53-55: 18-2, 50-54 


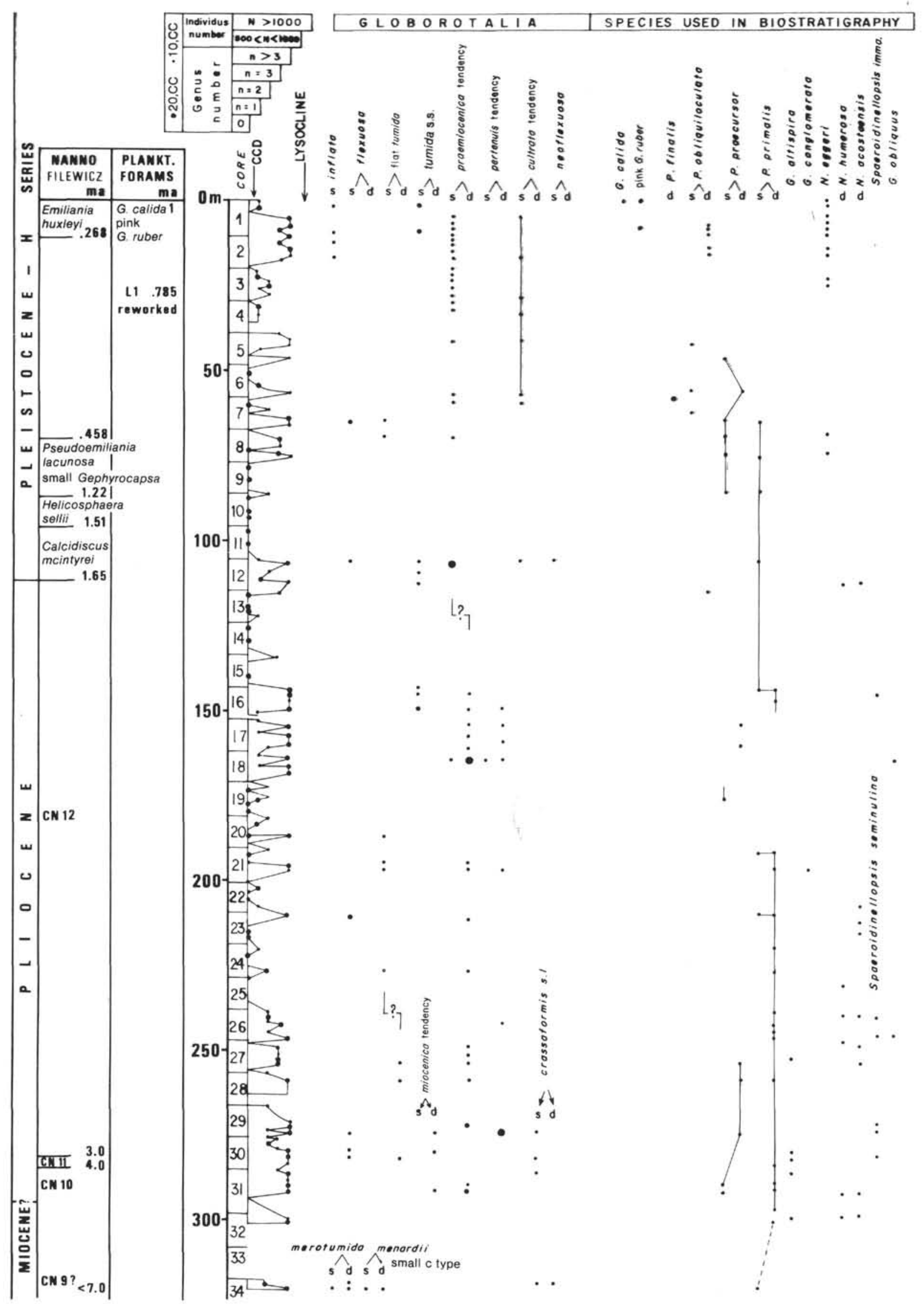

Figure 7. Biostratigraphic summary of Site 565 (see Fig. 4). 


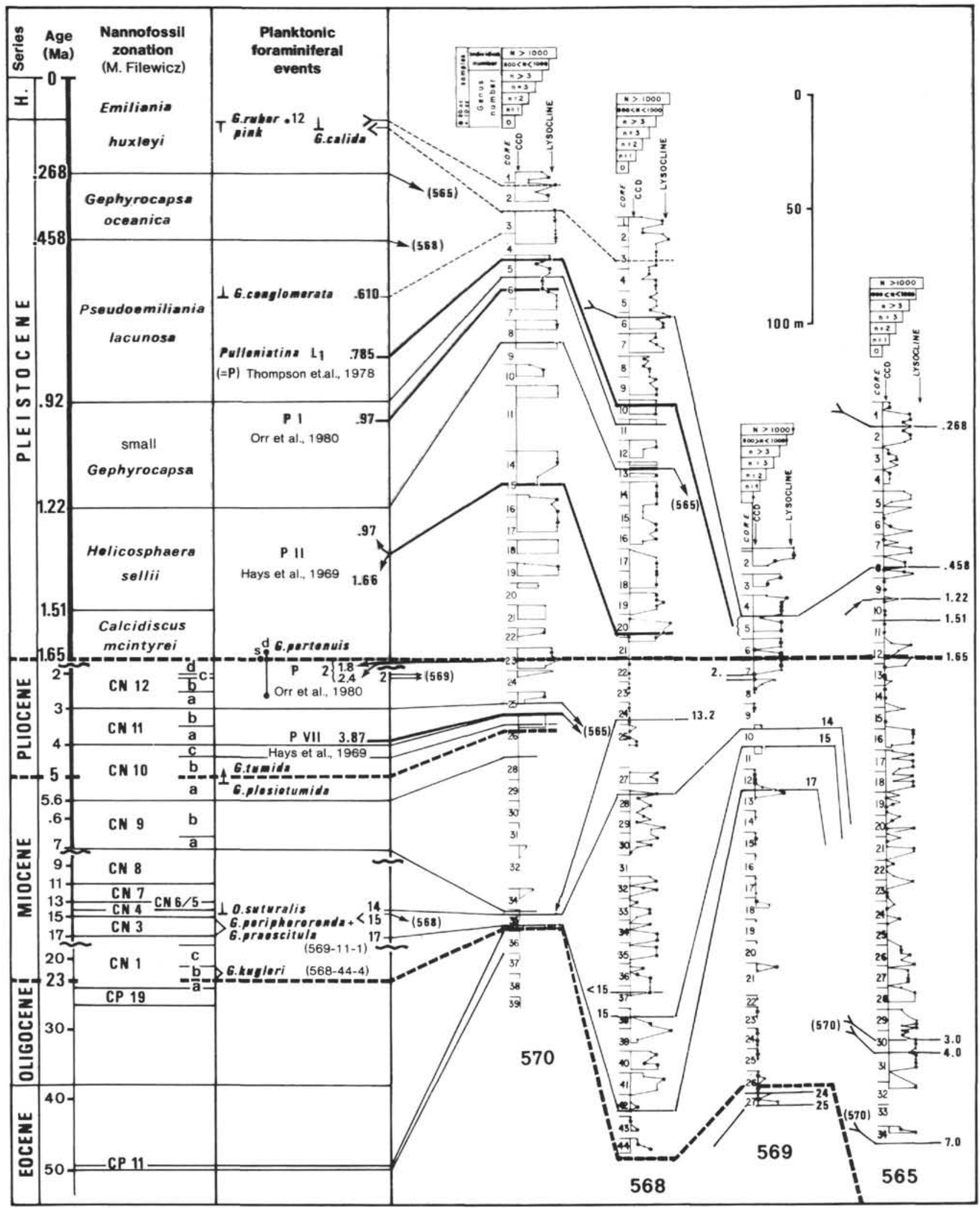

Figure 8. Biostratigraphic correlations of Sites 570, 568, 569, and 565. In the planktonic foraminiferal events column, PI, PII, and PVII, and P2 refer to Pulleniatina coiling changes (see Fig. 2 for references). 
1.22 and $1.65 \mathrm{Ma})$ at Site $570(570-15-2,55-56 \mathrm{~cm})$ and Site 568 (568-20-3, 75-77 cm).

The coiling change in both Pulleniatina primalis, and P. obliquiloculata dated between 1.87 and $2.47 \mathrm{Ma}$ at Site $570(570-23-4,66-70 \mathrm{~cm})$ supports the position of the Pliocene/Pleistocene boundary between Sections 57023-4 and 570-23-6, on the basis of nannofossil data (Filewicz, this volume). The coiling change of Pulleniatina primalis just above the Gilbert " $a$ " event $(3.87 \mathrm{Ma})$ is at Site 570 between Cores 570-26-1 and 570-25-3.

In the Miocene only the first appearance of two Fohsella species can be used at Site 568: $F$. peripheroacuta Fa in Core 568-29 (about $15 \mathrm{Ma}$ ) and $F$. praefohsi FA in Core 568-27 (about $14 \mathrm{Ma}$ ).

The biostratigraphic correlations (Fig. 8) show how the sedimentation rate varies from site to site. In order to evaluate better gaps in the record, we made a graphic representation (Fig. 9) of the sedimentation rates and of planktonic shell preservation at all sites. In Figure 9 the Leg 84 sites are positioned according to their water depths. From an examination of this figure it can be seen that it is not possible to obtain from these poor sequences a complete record of Globorotalia phyletic history except for the Pleistocene. The presence of preserved species and morphotypes of the Globorotalia group in these sections, however, provides useful information on their geographic distribution.

\section{GLOBOROTALIA REMAINS FROM LEG 84}

A number of steps in Globorotalia phyletic history are documented in our samples, but because of stratigraphic gaps and strong dissolution (Figs. 4-7), a detailed phyletic study is not possible.

Species of the Fohsella and the G. menardii lineages are well represented at Site 568 in the lower and middle Miocene (Plate 1, Figs. 16-20). After a gap, equivalent to about $7 \mathrm{Ma}, G$. merotumida is found in association with forms of the G. menardii plexus in the upper Miocene at Sites 565 and 570. A second gap of information precludes the identification of the evolutionary appearance of $G$. plesiotumida. This species occurred only at Site 570 about $4.4 \mathrm{Ma}$.

Pliocene Globorotalia are preserved at Site 565 (Plate 2), but their stratigraphic ordering is probably disturbed. Coiling changes occurred first in the "flat" G. tumida at about $2.7 \mathrm{Ma}$, followed shortly by a change in the $G$. praemiocenica and the $G$. aff. pertenuis multicamerata forms at about $2 \mathrm{Ma}$. From dextral all those forms become sinistral. Malmgren et al. (1983) described the evolution of $G$. tumida on the Ninetyeast Ridge in the southern Indian Ocean using eigenshape analysis. They give a listing of the various coiling changes of that species: dextral forms occur at 3.8, 5.3, and between 6.4 and 10.4 Ma. The dextral "flat" G. tumida seen in core 565-30 are from the middle Pliocene and fit well with the datum of 3.8 Ma given by Malmgrem et al. (1983). But in Cores 565-28 and 565-27, G. tumida are still dextral and probably reworked. At Site 570 , randomly coiled G. tumida, dated $3.87 \mathrm{Ma}$, occur in Core 570-26, which shows that this core is stratigraphically slightly lower than Core 30 at Site 565, in agreement with the nannofossil zonation. According to Filewicz (this volume), Core 570-26 dates from $\mathrm{CN} 10$ and Core $565-30$ is from CN11.

At Site 570 globorotaliids showing an affinity with $G$. pertenuis occurred in an interval between approximately 3 and $3.87 \mathrm{Ma}$. This occurrence may support the suggestion that the Panama isthmus was still open at that time (Keigwin, 1982c). The identification of G. pertenuis, however, presents some ambiguities. Our own observations on living globorotaliid populations in an upwelling area in the Arabic Sea $\left(8^{\circ} 21^{\prime} 5 \mathrm{~N}, 75^{\circ} 58^{\prime} \mathrm{E}\right.$, during a cruise on the Marion Dufresne, 1977) show homeomorphs from both $G$. pertenuis and "flat" G. tumida with a weak flexuosa tendency. In a sediment trap located in the East Equatorial Pacific, in the loop of the North Equatorial Counter Current $\left(12^{\circ} 50^{\prime} \mathrm{N}, 103^{\circ} 58^{\prime} \mathrm{W}\right)$ at $2560 \mathrm{~m}$ water depth, we collected a globorotaliid assemblage with a large variety of morphotypes. Some of those show many common characters with the Pliocene $G$. pertenuis. We believe therefore that in a particular environment, chiefly perhaps in an upwelling area, the globorotaliids are able to develop variable morphologies. Unfortunately, no sample of living planktonic assemblages from this area of study was available to us for comparison.

Quaternary globorotaliids from leg 84 (Plates 3 and 4) show cyclical changes in morphologies. Two basic morphotypes with opposite tendencies can be distinguished (Plate 4): the cultrata group and the tumida group with many intermediate forms resembling members of the G. limbata-G. praemiocenica lineage. We use here the names cultrata and tumida according to their etymological meanings of edged (tonsorus culter $=$ razor) and swollen (uva tumida, like a grape) and not as species names, as we do not know how many species are distinguishable in the group. In the sedimentary record available here (incomplete because of dissolution), we found a tumida plexus with a flattening tendency at various levels. We do not know if these tendencies are the result of a run-over of invaders of different morphologies or if globorotaliids are able to change their morphology as (in a crude comparison) oysters do. We believe that it is useful to identify these morphological changes to see if they are of biostratigraphic or ecological value. Therefore in Figures 4 to 7 we distinguished the main morphological tendencies recognized at every level. Comparing the sites it can be seen that true G. tumida occur only in the lower Pleistocene, then disappear to reappear in the upper Quaternary. Dissolution is not the cause of the disappearance, because in many levels barren of G. tumida, G. cultrata are preserved. Often $G$. aff. praemiocenica replace $G$. cultrata. Some "fimbriate" forms occur at Site 570 and 568 slightly below and slightly above the Pulleniatina $\mathrm{L}_{1}$ datum $(0.785 \mathrm{Ma})$.

We need the results of an integrated biostratigraphy for careful selection of levels to compare from site to site and we also need to know the distribution of living morphotypes in the various water masses in the studied area to check our hypothesis: a better knowledge of the morphological variations in the globorotaliids should permit 


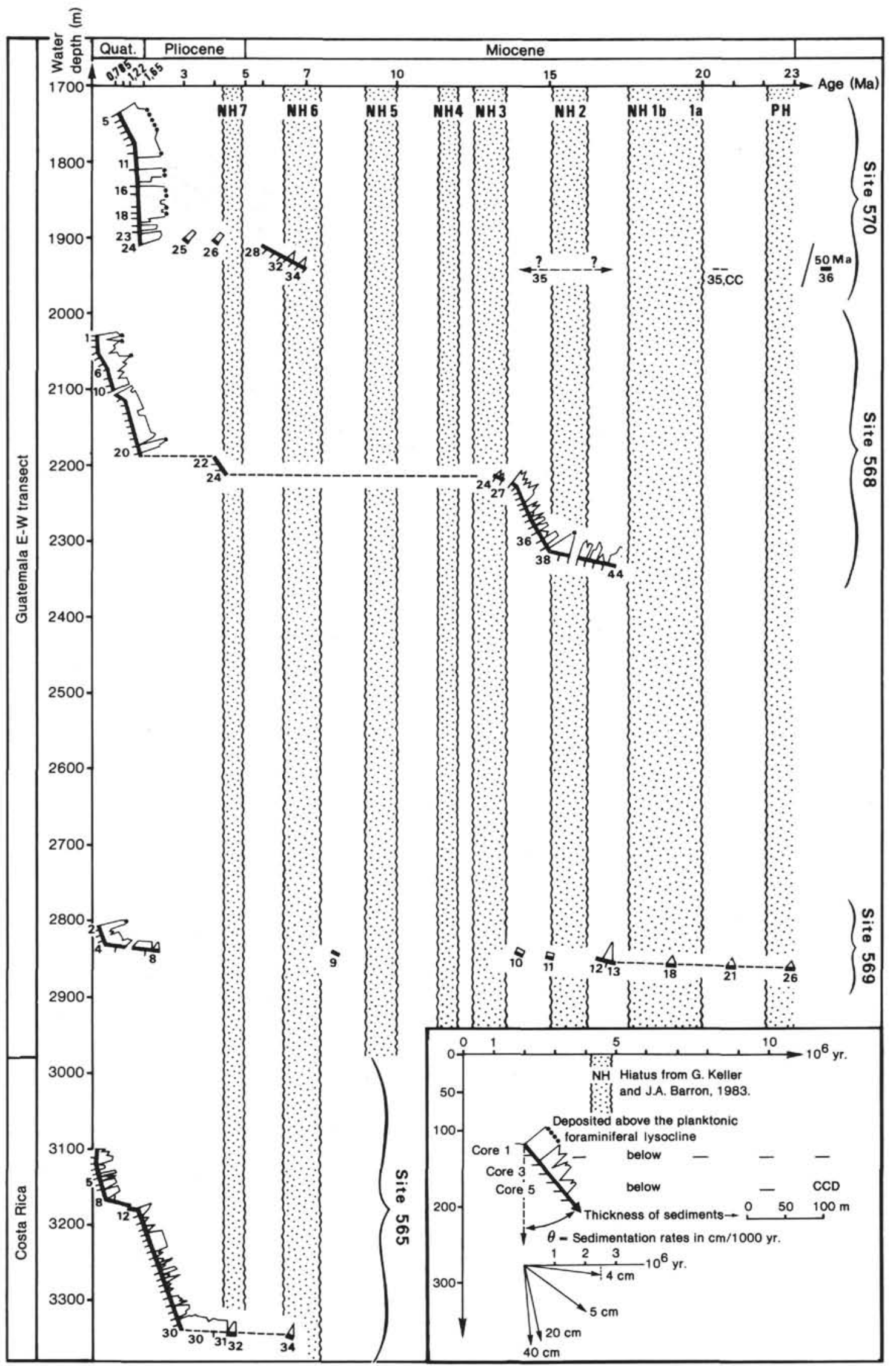

Figure 9. Sedimentation rates and intensity of dissolution at Sites 570, 568, 569, and 565. 
detailed biostratigraphic correlations and an understanding of the evolution of the water masses and oceanic circulation with time (Romine, 1983).

\section{ADDENDUM}

The phylogenetic atlas by J. P. Kennett and M. S. Srinivasan (1983), Neogene Planktonic Foraminifera, became available to us after we had finalized this chapter. In many instances the taxonomy used in this paper is in agreement with that of Kennett and Srinivasan, however, the following comments are relevant to this study.

Following Bolli and Saunders (1982), in this chapter we grouped together G. siakensis and G. mayeri. However, forms with radial sutures at the spiral and umbilical faces can be distinguished (as siakensis) from the true mayeri, with curved sutures at the spiral face. For example, the specimen illustrated in Plate 1, Figures 7-9 appears as an intermediate form between $P$. semivera and $P$. siakensis sensu Kennett and Srinivasan.

We did not find in Kennett and Srinivasan (1983) a figuration of Pleistocene Globorotalia showing a praemiocenica "tendency" nor a Pliocene "flat" tumida.

Kennett and Srinivasan use Menardella menardii as a form ranging from the Miocene to the Recent. However, as discussed in this study, we can distinguish steps in the morphological evolution of this form. There is a tendency for the spiral to increase more quickly and the umbilica area to open. That can be seen when we compared the diameters of the last and penultimate whorl in spiral view. If we are able to distinguish $G$. limbata we would like to give a special name to the Quaternary Menardella: cultrata seems appropriate.

\section{ACKNOWLEDGMENTS}

We are indebted to the Deep Sea Drilling Project and National Science Foundation for providing us with samples. W. Berger gave us valuable advice on how to evaluate dissolution. M. Filewicz gave us insight into some biostratigraphic points. We extend special thanks to $\mathrm{E}$. Vincent for improving the text. Thanks are due also to A. Fleminger and D. Snyder for trying to find adequate plankton tow samples for us for comparison purposes. Mrs. Guillaume and Mrs. Andre helped us with SEM photos, J. Brouillet drafted figures and tables, and Mrs. Le Cam washed and weighed the samples. IPOD France provided us with funds that enabled us to work on these materials.

\section{REFERENCES}

Aubouin, J., von Huene, R., et l'équipe scientifique du leg 84 du Glomar Challenger, 1982. Subduction sans accrétion: la marge pacifique du Guatémala: premiers résultats du Leg 84 du Deep-Sea Drilling Project (janvier-février 1982). C.R. Acad. Sci. Paris, 294(II):803-812.

Barron, J. A., and Keller, G., 1982. Widespread Miocene deep-sea hiatuses: coincidence with periods of global cooling. Geology, 10: 577-581.

Barron, J. A., Poore, R. Z., and Wolfart, R., 1981. Biostratigraphic summary. In Yeats, R. S., Haq, B. U,. et al., Init. Repts. DSDP, 63: Washington (U.S. Govt. Printing Office), 927-941.

Bé, A. W. H., and Hamlin, W. H., 1967. Ecology of Recent planktonic Foraminifera: Part 3. Distribution in the North Atlantic during the summer of 1961. Micropaleontology, 13:87-106.

Bé, A. W. H., Morse, J. W., and Harrison, S. M., 1975. In Sliter, W. V., Bé, A. W. H., and Berger, W. H., Dissolution of deep-sea carbonates. Cushman Found. Foraminiferal Res. Spec. Publ., 13: $27-55$.

Berger, W. H., 1970. Planktonic Foraminifera: selective solution and the lysocline. Mar. Geol., 8:111-138.

Berger, A. W. H., and Piper, D. J. W., 1972. Planktonic Foraminifera: differential settling, dissolution, and redeposition. Deep-Sea Res., $15: 31-43$.

Bizon, G., and Glaçcon, G., 1978. Morphological investigations on the genus Globorotalia from Site 372. In Hsü, K., Montadert, L., et al., Init. Repts. DSDP, 42, Pt. 1: Washington (U.S. Govt. Printing Office), 687-707.

Blow, W. H., 1969. Late middle Eocene to Recent planktonic foraminiferal biostratigraphy. In Bronnimann, P., and Renz, H. H. (Eds.), Proc. Ist. Int. Conf. on Planktonic Microfossils, Geneva, 1967, E. J. Brill (Leiden), 2:199-421.
Bolli, H. M., 1966. Zonation of Cretaceous to Pliocene marine sediments based on planktonic foraminifera. Bol. Inf. Asoc. Venez. Geol. Min. Pet., 9:3-12.

Bolli, H. M., and Premoli Silva, I., 1973. Oligocene to Recent planktonic Foraminifera and stratigraphy of the Leg 15 sites in the Caribbean Sea. In Edgar, N. T., Saunders, J. B., et al., Init. Repts. DSDP, 15: Washington (U.S. Govt. Printing Office), 475-497.

Bolli, H. M., and Saunders, J. B., 1982. Globorotalia mayeri and its relationship to Globorotalia siakensis and Globorotalia continuosa. J. Foraminif. Res., 12:39-50.

Bonneau, M. C., Vergnaud-Grazzini, C., and Berger, W. H., 1980. Stable isotope fractionation and differential dissolution in recent planktonic foraminifera from Pacific box-cores. oceanol. Acta, 3: 377-382.

Bradshaw, J. S., 1959. Ecology of living planktonic Foraminifera in the North and Equatorial Pacific Ocean. Contrib. Cushman Foraminiferal Res., 10:25-44.

Cifelli, R., 1982. Early occurrences and some phylogenetic implications of spiny, honeycomb textured planktonic Foraminifera. $J$. Foraminif. Res., 12:105-115.

Coulbourn, W. T., Parker, F. L., and Berger, W. H., 1980. Faunal and solution patterns of planktonic Foraminifera in surface sediments of the North Pacific. Mar. Micropaleontol., 5:329-399.

Hays, J. D., Saito, T., Opdyke, N. D., and Burckle, L. H., 1969. Pliocene-Pleistocene sediments of the Equatorial Pacific: their paleomagnetic, biostratigraphic, and climatic record. Bull. Geol. Soc. Am., 80:1481-1514.

Kaneps, A. G., 1973. Cenozoic planktonic Foraminifera from the eastern equatorial Pacific Ocean. In van Andel, T. H., Heath, G. R., et al., Init. Repts. DSDP, 16: Washington (U.S. Govt. Printing Office), 713-745.

Keigwin, L. D., Jr., 1982a. Neogene planktonic foraminifers from Deep Sea Drilling Project Sites 502 and 503. In Prell, W. L., Gardner, J. V., et al., Init. Repts. DSDP, 68: Washington (U.S. Govt. Printing Office), 269-288.

1982b. Stable isotope stratigraphy and paleoceanography of Sites 502 and 503. In Prell, W. L., Gardner, J. V., et al., Init. Repts. DSDP, 68: Washington (U.S. Govt. Printing Office), 445-453.

1982c. Appendix: basis for age assignments at Deep Sea Drilling Project Sites 502 and 503 In Prell, W. L., Gardner, J. V., et al., Init. Repts. DSDP, 68: Washington (U.S. Govt. Printing Office), 493-495.

Keller, G., 1980. Middle to Late Miocene datum levels and paleoceanography of the North and Southeastern Pacific Ocean. Mar. Micropaleontol., 5:249-281.

1981a. Planktonic foraminiferal faunas of the Equatorial Pacific suggest early Miocene origin of present oceanic circulation. Mar. Micropaleontol., 6:269-295.

$198 \mathrm{lb}$. The genus Globorotalia in the early Miocene of the equatorial and north western Pacific. J. Foraminif. Res., 11: 118-132.

Keller, G., and Barron, J. A., 1983. Paleoceanographic implications of Miocene deep-sea hiatuses. Bull. Geol. Soc. Am., 94:590-613.

Keller, G., Barron, J. A., and Burckle, L. H., 1982. North Pacific late Miocene correlations using microfossils, stable isotopes, percent $\mathrm{CACO}_{3}$ and magnetostratigraphy. Mar. Micropaleontol., 7:327-357.

Kennett, J. P., Srinivasan, M. S., 1983. Neogene Planktonic Foraminifera: Stroudsberg, Pennsylvania (Hutchinson Ross Publishing Co.).

Lowrie, W., and Alvarez, W., 1981. One hundred million years of geomagnetic polarity history. Geology, 9:392-397.

McGowran, B., 1968. Reclassification of early Tertiary Globorotalia. Micropaleontology, 14:179-198.

Malmgren, B. A., Berggren, W. A., and Lohmann, G. P., 1983. Evidence of nongradualism and nonpunctualism in the Globorotalia tumida lineage (planktonic Foraminifera). Paleobiology, 9(4): 377-389.

Martini, E., 1971. Standard Tertiary and Quaternary calcareous nannoplankton zonation. Proc. 2nd Int. Conf. Planktonic Microfossils, Roma, 1970, 2:739-786.

Minster, J. B., and Jordan, T. H., 1978. Present-day plate motions. $J$. Geophys. Res., 83:5331-5354.

Okada, H., and Bukry, D., 1980. Supplementary modification and introduction code numbers to the low-latitude Coccolith biostrati- 
graphic zonation (Bukry, 1973-1975). Mar. Micropaleontol., 5: 321-325.

Orr, W. N., 1967. Variation and distribution of Globigerinoides ruber in the Gulf of Mexico. Micropaleontology, 15:373-379.

Orr, W. N., and Jenkins, D. G., 1977. Cenozoic planktonic Foraminifera zonation and selective test solution. In Ramsey, A. T. S. (Ed.), Oceanic Micropaleontology: London, New York, San Francisco (Academic Press), pp. 163-196.

1980. Eastern Equatorial Pacific Pliocene-Pleistocene biostratigraphy. In Memorial to Orville L. Bandy, Cushman Found. Foraminiferal Res. Spec. Publ., 19:278-286.

Parker, F. L., and Berger, W. H., 1971. Faunal and solution patterns of planktonic Foraminifera in surface sediments of the South Pacific. Deep-Sea Res., 18:73-107.

Romine, K., 1983. Late Quaternary history of atmospheric and oceanic circulation in the Eastern Equatorial Pacific. Mar. Micropaleontol., 7:163-187.

Ryan, W. B. F., Cita, M. B., Rawson, M. D., Burckle, L. H., and Saito, T., 1974. A paleomagnetic assignment of Neogene stage boundaries and the development of isochronous datum planes between the Mediterranean, the Pacific, and Indian Oceans in order to investigate the response of the world ocean to the Mediterranean "salinity crisis." Riv. Ital. Pal. Strat., 80:631-687.

Saito, T., Burckle, L. H., and Hays, J. D., 1975. Late Miocene to Pleistocene biostratigraphy of Equatorial Pacific sediments. In Sai- to, R., and Burckle, L. H. (Eds.), Late Neogene Epoch Boundaries: New York (Am. Mus. Nat. Hist., Micropaleontology Press), pp. 226-244.

Saito, T., Thompson, P. R., and Breger, D., 1981. Systematic Index of Recent and Pleistocene Planktonic Foraminifera: Tokyo (University of Tokyo Press).

Srinivasan, M. S., and Kennett, J. P., 1981. Neogene planktonic Foraminifera biostratigraphy and evolution: equatorial to sub-Antarctic, South Pacific. Mar. Micropaleontol., 6:499-533.

Thompson, P. R., and Sciarrillo, J. R., 1978. Planktonic foraminiferal biostratigraphy in the Equatorial Pacific. Nature, 276:29-33.

Thunell, P. R., and Honjo, S., 1981. Planktonic foraminiferal flux to the deep ocean: sediment trap results from the tropical Atlantic and the Central Pacific. Mar. Geol., 40:237-253.

Tjsalma, R. C., 1971. Stratigraphy and foraminifera of the Neogene of the Eastern Guadalquivir Basin (southern Spain). Utrecht Micropaleontol. Bull. 4:1-161.

Zachariasse, W. J., 1975. Planktonic foraminiferal biostratigraphy of the late Neogene of Crete (Greece). Utrecht Micropaleontol. Bull. 11:1-171.

Date of Initial Receipt: 4 August 1983

Date of Acceptance: 4 April 1984 


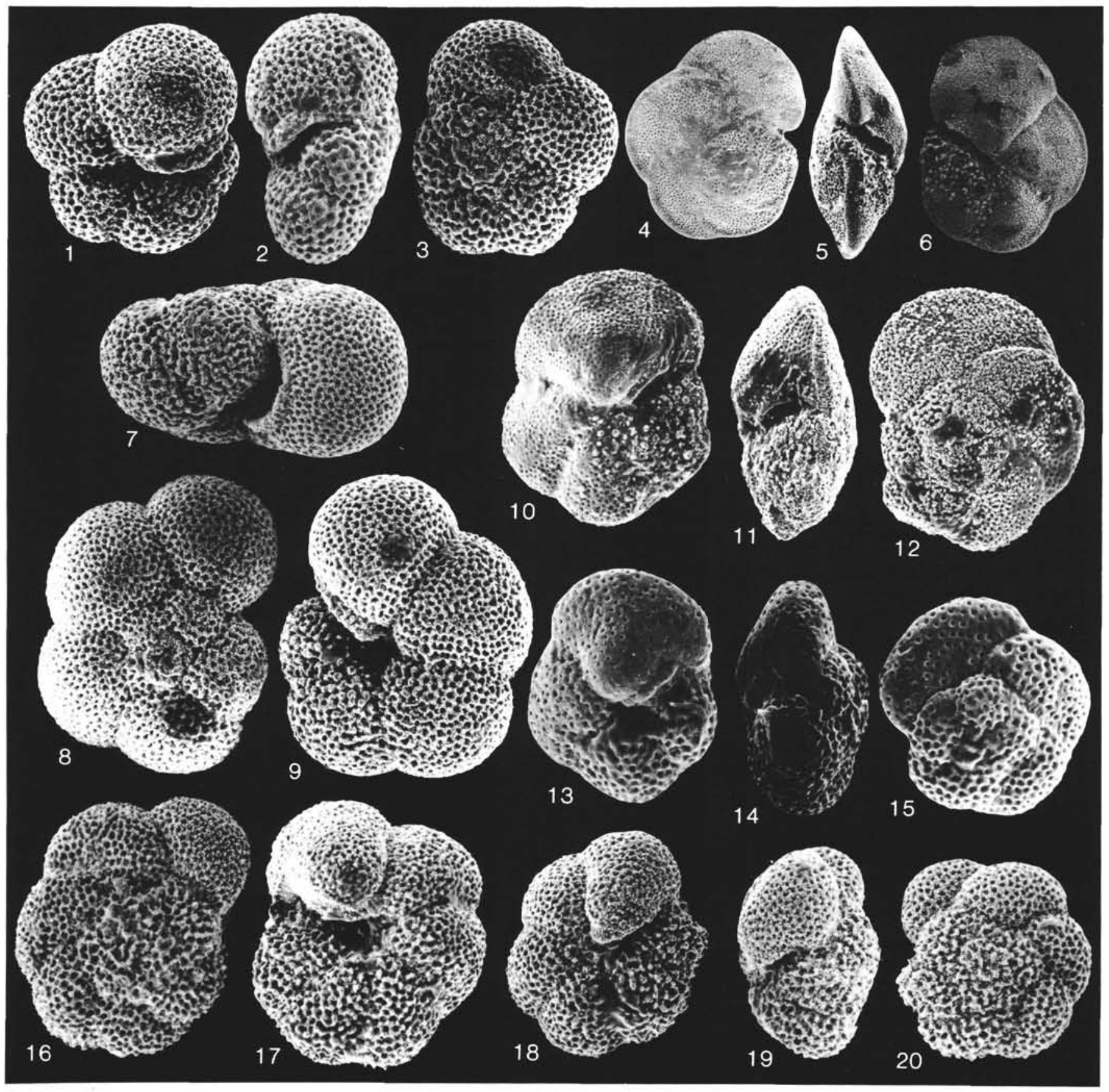

Plate 1. Globorotaliids of the early Miocene at Site 568. 1-3. Paragloborotalia nana (Bolli)-Neogloboquadrina continuosa (Blow) intermediate. Sample 568-44-4, 62-66 cm, $\times 190$. 4-6. Globorotalia praemenardii Cushman and Stainforth. Sample 568-32-1, 28-30 cm, $\times 125$. 7-9. Paragloborotalia mayeri Cushman and Ellisor emend. Bolli and Saunders (1982). Sample 568-44-4, 62-66 cm, $\times 190$. 10-12. Globorotalia praescitula Blow. Sample 568-36-1, 90-92 cm, $\times 190$. 13-15. Sinistral coiled "A"-type chambered primitive Globorotalia praescitula Blow. Sample 568-38-6, 108-110 cm, $\times 300$. 16-17 and 18-20. Dextral and sinistral coiled Fohsella kugleri (Bolli). Sample 568-44-4, 62-66 cm, $\times 190$. 


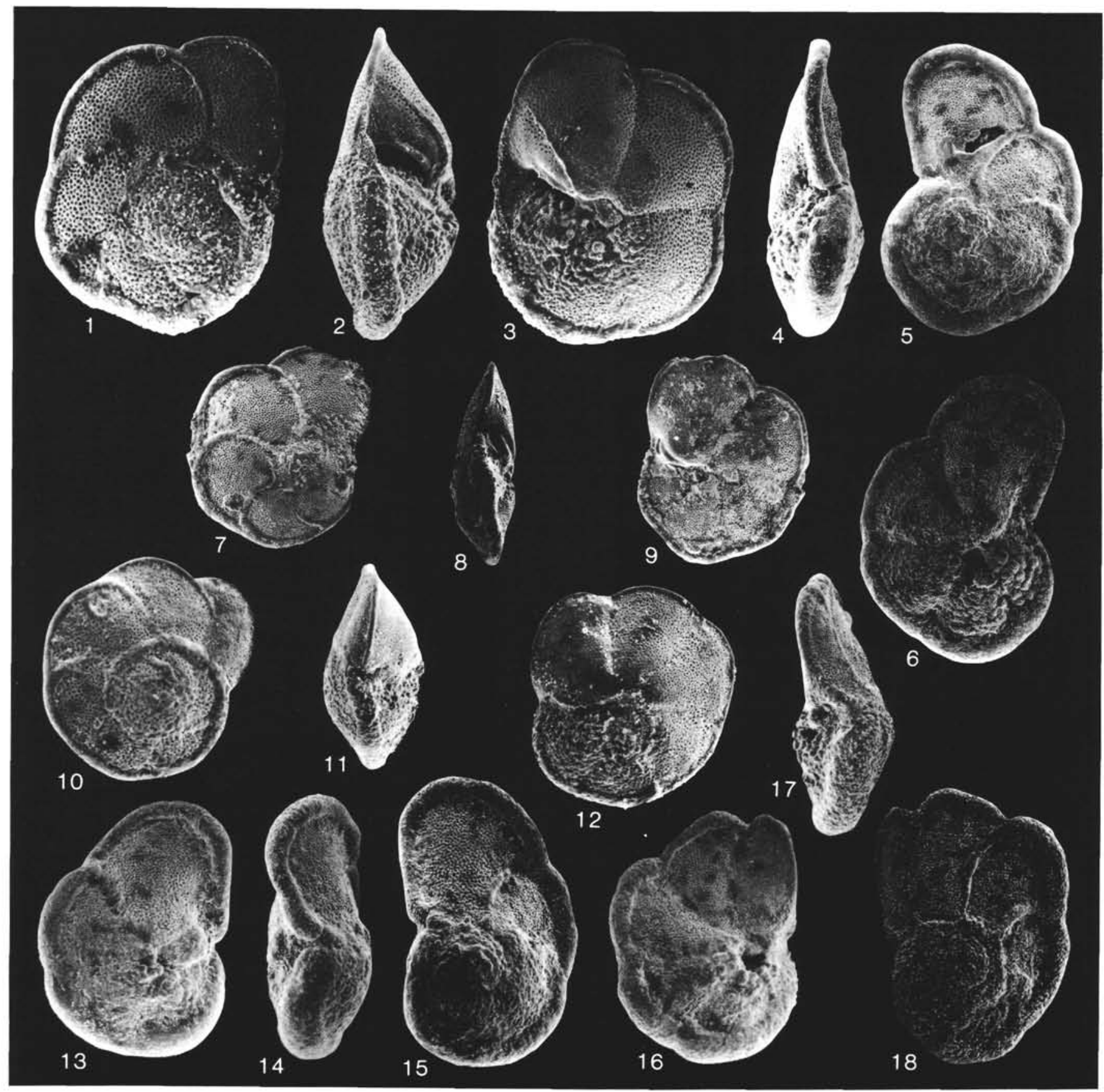

Plate 2. Globorotaliids of the early Pliocene at Site 565. 1-3. Dextral " $G$. miocenica" tendency. Sample 565-31-4, 88-91 cm, $\times 125$. 4-6. Sinistral "flat G. tumida," Sample 565-31-3, 73-75 cm, $\times 60$. 7-9. Dextral G. limbata (Fornasini). Sample 565-31-3, 73-75 cm, $\times 60.10-12$. Dextral $G$. praemiocenica Lamb and Beard. Sample 565-33-2, 16-20 cm, $\times 90$. 13-15. Intermediate between "flat G. tumida" and G. flexuosa (Koch). Sample 565-33-2, 16-20 cm, $\times 90$. 16-18. Sinistral G. flexuosa (Koch). Sample 565-33-2, 16-20 cm, $\times 60$. 


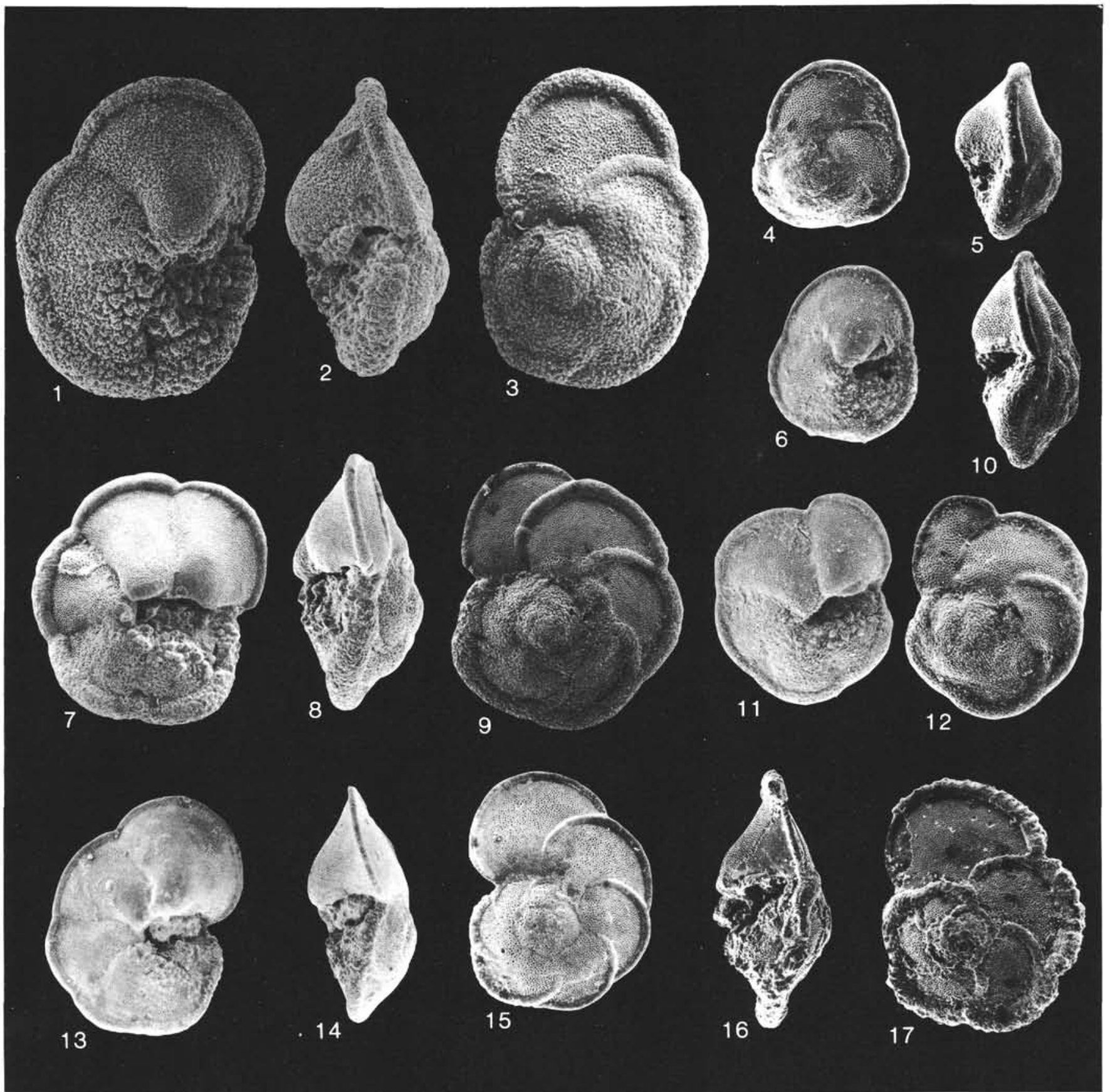

Plate 3. Quaternary Globorotalia. 1-3. G. tumida (Brady). Sample 569-1-1, 26-28 cm, $\times 60$. 4-6, 7-9, 10-12, and 13-15. Four specimens showing the "G. praemiocenica" tendency in the $G$. tumida plexus. (4-6 and 10-12) Sample 568-14-1, 15-17 cm, $\times 60$; (7-9) Sample 569-1-1, 26$28 \mathrm{~cm}, \times 90$; (13-15) Sample 570-14-1, 14-16 cm, $\times 60$. 16, 17. The "fimbriate" tendency in Sample 568-6-1, 28-29 cm, $\times 60$. 


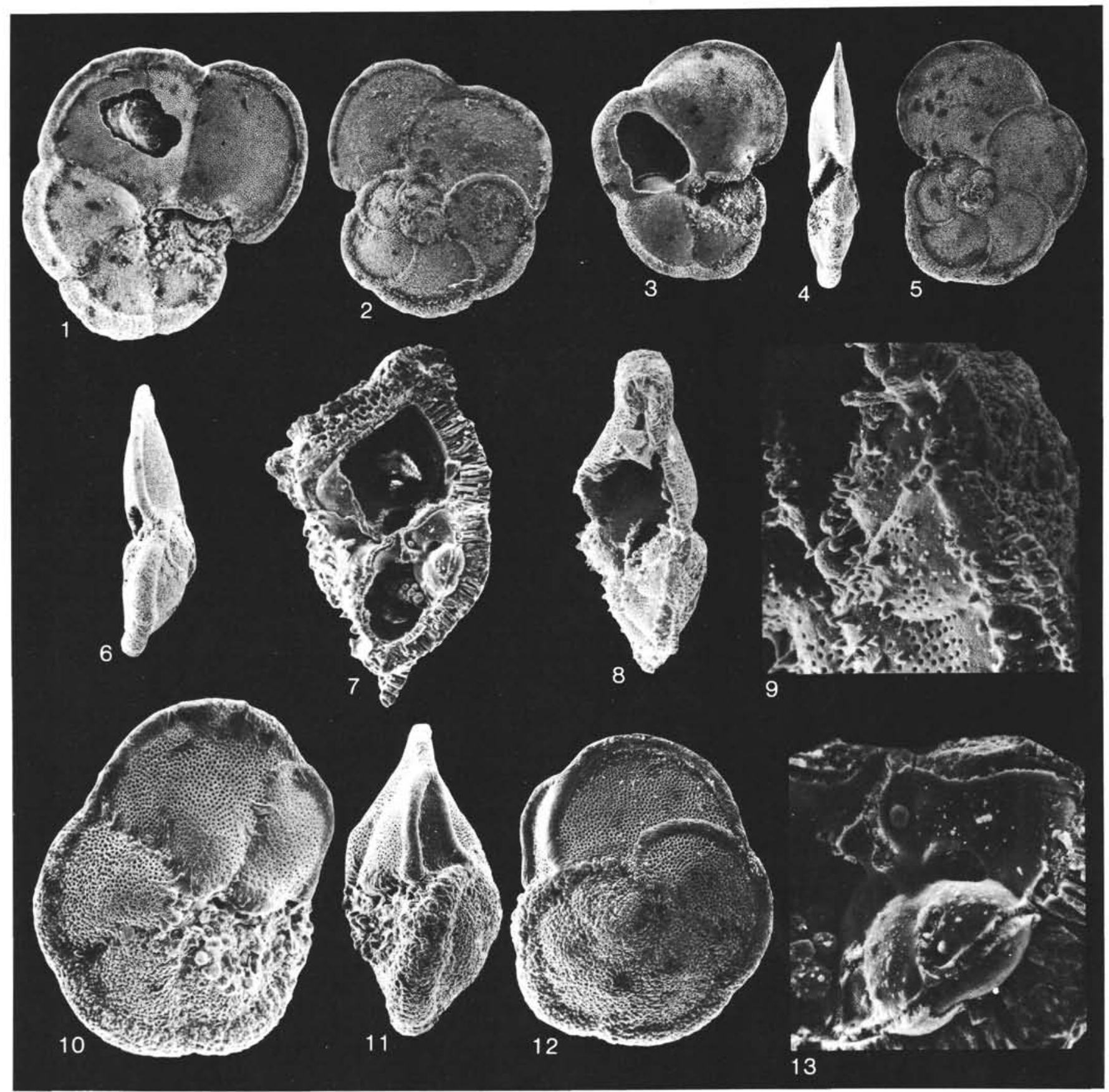

Plate 4. Some Globorotalia of the late Quaternary from Sample 568-1-1, 50-52 cm. 1, 2, and 6; 3-5, and 8-9. Two specimens illustrating the " $G$. cultrata" tendency, $(1,2,6)$ sinistrally coiled specimen, $\times 45,(3-5,8-9)$ sinistrally coiled very flat biconvex specimen, $\times 42,(8-9)$ the same specimen with the three last chambers removed to show the imperforated band along the keel on the umbilical face of the chambers of the penultimate whorl, (8) $\times 125,(9) \times 420$. 7, 10-13. Illustration of the " $G$. tumida" tendency: 1a-12a sinistral specimen, $(10-12) \times 90,(7,13)$ an approximately axial section of the same specimen, which allows us to compare the wall of the last whorl with that of Figure 8 and to study the imperforate juvenile stage, $(7) \times 190,(13) \times 600$. 